\title{
Geochemical and Geophysical Study in a Degraded Area Used for Disposal of Sludge from a Water Treatment Plant
}

\author{
Ricardo Cosme Arraes Moreira, ${ }^{1,2}$ Geraldo Resende Boaventura, ${ }^{2}$ Sandra Alves Nunes, ${ }^{1}$ \\ Luciano de Almeida Pinheiro, ${ }^{3}$ Carlos Tadeu Carvalho do Nascimento, ${ }^{2}$ \\ Davi Rodrigues da Silva, ${ }^{1}$ and Christiane de Pinna Lira ${ }^{1}$
}

${ }^{1}$ Laboratório B Companhia de Saneamento Ambiental do Distrito Federal, SAIN Área Especial ETA CAESB, Asa Norte,
$72620-000$ Brasília DF, Brazil
${ }^{2}$ Instituto de Geociências, Campus Universitário Darcy Ribeiro, Universidade de Brasília, 70910-900 Brasília DF, Brazil
${ }^{3}$ Setor de Laboratórios, Embrapa Cerrados, BR $020 \mathrm{~km}$ 18, Rodovia Brasília-Fortaleza, 73310-970 Planaltina DF, Brazil

Correspondence should be addressed to Ricardo Cosme Arraes Moreira, rcam@unb.br

Received 15 November 2010; Accepted 25 January 2011

Academic Editor: Rodrigo Studart Corrêa

Copyright ( 2011 Ricardo Cosme Arraes Moreira et al. This is an open access article distributed under the Creative Commons Attribution License, which permits unrestricted use, distribution, and reproduction in any medium, provided the original work is properly cited.

\begin{abstract}
The effects of disposal of sludge from water treatment plant (WTS) in area damaged by laterite extraction and its consequences to soil and groundwater were investigated. Therefore, the presence and concentration of anthropogenic elements and chemical compounds were determinated. WTS disposal's influence was characterized by electroresistivity method. The WTS's geochemical dispersion was noticed in the first meters of the nonsaturated zone from the lending area. Lateritic profiles were characterized due to the large variation in chemical composition between the horizons. Infiltration and percolation of rainwater through the WTS have caused migration of total dissolved solids to the groundwater. WTS's disposing area has more similarities to local preserved vegetation than to gravel bed area. WTS can be considered a noninert residue if disposed in degraded areas located in regions with similar geological and hydrochemical characteristics.
\end{abstract}

\section{Introduction}

The global scale environmental changes resulting from anthropic process of space occupation and urbanization impose fees which are incompatible with the carrying capacity of natural ecosystems. In this context, surface waters have been increasingly penalized with several launches of waste resulting from populational growth and disorderly occupation of protected areas.

Thus, water quality worsens, and making it drinkable requires treatment with greater quantities of chemicals than usual to be applied. As a result, waste increases in water treatment plants (WTPs) such as the sludge generated in clarifiers and water resulting from the filter washing.

In Brazil, there are about 7,500 WTPs, called conventional or traditional, which use coagulation/flocculation/sedimentation and filtration systems for water treatment. These systems generate wastes in the clarifiers and filters that, in most cases, are released directly into rivers, lakes, and reservoirs, aggravating the environmental issue [13].

The chemical sludge produced by the water treatment plants is an extremely gelatinous material composed by aluminum hydroxides, inorganic particles such as clay and silt, color colloids and microorganisms including plankton, and other organic and inorganic materials, which are removed from the treated water, or from the chemicals added to the process $[4,5]$. Its $\mathrm{pH}$ range is from 5 to 7 , which is insoluble in the range of natural water $\mathrm{pH}$.

It is estimated that in Brazil about 2,000 tons/day of WTS are dumped directly into waterways without any treatment [6]. This practice contributes to the organic pollution, which may consume the oxygen dissolved in the water course, leading to anaerobic conditions, producing odors, excessive growth of algae, and fish mortality [7]. Some studies have shown the chronic toxicity of this material to aquatic 
organisms, as well as the degradation of water quality and sediment [8-10].

Several alternatives have been presented for the recovery of such waste, particularly the immobilization of phosphorus (P), which avoids the risk of water eutrophication and, under certain conditions, can even provide gains in agriculture [1117].

Due to the characteristics of chemical sludge, its use on degraded areas or parks can benefit the soil [7]. R. C. A. Moreira et al. [5] studied the influence of provisioning WTS in a gravel pit. They analyzed minerals and sample composition taken from several surveys, employing geophysical prospecting techniques in the area. Results showed that geochemical distribution of elements in subsurface was strongly associated with the variation of mineral composition and granulometry in soils profiles. Nutrients were being transferred to deep soil layers, enabling development of local vegetation. These facts were considered positive for the use of this material in recovering degraded areas. Lenzi et al. [18] also identified applications of sludge in soil remediation. A. A. Moreira et al. [19] characterized the sludge from the Rio Descoberto Water Treatment Plant and found high levels of micronutrients such as $\mathrm{Zn}, \mathrm{Fe}, \mathrm{Mn}$, and $\mathrm{Cu}$, and also organic matter. Potential acidity was considered high, providing that conditions for the retention of anions in the WTS were largely favourable. However, low effective cation exchange capacity, CEC, indicated that the material can release ions into the water column. These results, associated with the deficiency in $\mathrm{Ca}^{2+}, \mathrm{K}^{+}$, and $\mathrm{P}$, made the use of the WTS impracticable as a soil amendment, but favorable to recover degraded areas.

At the Rio Descoberto Water Treatment Plant, sludge from filter washing is centrifuged and, since March 1997, sent to the deactivated gravel bed [20]. This WTP has a nominal capacity of $6,000 \mathrm{~L} / \mathrm{s}$, uses ferric aluminum sulfate coagulant to treat water from the Descoberto Lake, and works heavily with automated processes. WTS annual production in this plant exceeds 2,000 tons.

In the Distrito Federal, activities for sand, gravel, clay, and grit extraction respond for almost all degraded areas [21]. This type of mining is characterized by low investment, lack of technological support in the early stages of production, environmental control, and recovery of mined areas. Use of gravel bed for final sludge disposal is adopted in the Distrito Federal, but few studies have shown the risks that material components can bring to these mined areas.

Barroso and Cordeiro [22] warn from the toxic action of metals and the presence of $\mathrm{Al}$ in the WTS, with positive or negative effects to the treatment processes, disposal and reuse of the waste. The Al mobility in the soil or in the treated water can be harmful, especially because this element is not considered essential for plants and animals, and no biochemical function in organisms is known to be dependent on this metal [23]. The $\mathrm{Al}$ is partitioned in the biota by its differences in acid-base affinity, by its kinetic, by temporal form, and spatially by the membranes and the compartments. One aspect of the toxicity of this metal, although not unique, is the chemical combination between metal and ligands in the organism [24].
Echart and Cavalli-Molina [25] studied the phytotoxicity of the $\mathrm{Al}$ and found that the metal is one of the major causes of reduced growth in economically important plants occurring in acid soils. That is because in tropical and subtropical humid soils, with high rainfall, soluble nutrients such as $\mathrm{Ca}, \mathrm{Mg}, \mathrm{K}$, and other basic elements are leached, resulting in the decrease of $\mathrm{pH}$ and mineralization of organic matter by soil microorganisms. At low $\mathrm{pH}$, the $\mathrm{H}^{+}$acts on minerals by releasing ions $\mathrm{Al}$, which are predominantly held by negative charges of the clay soil in equilibrium with the $\mathrm{Al}^{3+}$ in solution [26].

This study intended to identify the effects of WTS disposal in a degraded area by laterite extraction (gravel bed) and its consequences to soil and groundwater. It was intended to determine the existence, concentration, and mobility of anthropogenic elements and chemical compounds through geophysical and geochemical studies by comparing the local subdued to WTS's disposal and other adjacent regions still less impacted, as a baseline.

\section{Experimental Part}

2.1. Study Area. This study was carried out in the Distrito Federal, central Brazil. Climate in the region is characterized by two distinct periods, a dry season, from May to September, with low rainfall, high evaporation rates, and low values of relative humidity, sometimes below $15 \%$; a rainy season, from October to April, with approximately a rainfall of 1,450 mm (October/2007 to April/2008, Melchior Sewage Treatment Plant; source: PHIHM/CAESB). Average temperature varies from $19^{\circ} \mathrm{C}$ between June and July to $22^{\circ} \mathrm{C}$ between March and September [27].

In the Distrito Federal, there are metasedimentary rocks belonging to Paranoá, Canastra, Araxá, and Bambuí groups, mainly distinguished by regional correlations with other areas of the Brasília Belt, deformation intensity, metamorphism, and the nature of the lithotype.

The Paranoá Group corresponds to a psamo-peliticcarbonated unit of Mesoproterozoic age interpreted as a sequence of plataformal deposition with variations in water depth over time [28]. Freitas-Silva and Campos [29] describe the tertiary-quaternary coverage as coming from chemical weathering processes during the Cenozoic, mainly under geological, climatic, topographical, and morphological constraints, among others. These processes provided the development of an extensive weathering mantle that reaches thicknesses greater than 50 meters.

The studied site, which corresponds to a disabled gravel pit, is located near the city of Ceilândia, DF (Figure 1). In this area, water treatment residue from Descoberto Lake is being disposed directly into the exposed regolith, after extraction of lateritic crust. The lateritic ferruginous breastplates constitute the so-called "gravel," which occur at the edges of the plateaus (altitude 1050-1150 m). This gravel is positioned on the R4 Unit from Paranoá Group, of Meso/Neoproterozoic age, according to the Geological Map of Distrito Federal, [30].

Mineral composition of the soils in the area varies in content of quartz and illite, corresponding to the own 
TABLE 1: Monitoring wells located upstream (Upstream P), downstream (Downstream P), and in the area of disposal of WTS (WTS P). Datum: Astro Chuá.

\begin{tabular}{lccc}
\hline Monitoring well & UTML & UTMN & Elevation $(\mathrm{m})$ \\
\hline Upstream P & 804752 & 8246764 & 1101 \\
Downstream P & 804903 & 8246729 & 1096 \\
WTS P & 804944 & 8246833 & 1101 \\
\hline
\end{tabular}

lithotype - the clayey metarhythmite (R4) - formed by the intercalation of sandy and pelitic levels. Intensity of illite peaks tends to be large in the sample relating to pelitic levels, in which quartz is the constitutional trait or was not identified. Moreover, this is the minor constituent in sand levels. Goethite corresponds to the lateritic level formed by supergene enrichment in iron and is present throughout the study area [31].

The original soil profile in the gravel-mine no longer exists, due to the removal of the lateritic coverage. The sludge is disposed directly on the regolith, defined as that decomposed material that lies on the matrix rock, without transportation.

The WTS disposal area corresponds to a plateau with about $75,000 \mathrm{~m}^{2}$, with an average slope of $3.5 \%$ at its longest extension (NE-SW). The drainage lines have a south-east direction preferably, culminating at about 500 meters in the Córrego do Meio (also known as Matadouro).

Although the area has been modified in its original aspect, it is still possible to identify savanna fragments vegetation in preserved areas.

The depth of phreatic surface is higher than $10 \mathrm{~m}$ throughout the studied area. Two wells were found in the region, one deep well downstream of the area and one shallow well upstream (cistern). Although both are disabled, the cistern is being used as a septic tank.

The WTS disposal local is surrounded by access roads and small farms, occurring degraded areas with low rate of revegetation. It is customary in the local community, the use of gullies and ravines as garbage dumps, which facilitates transport of contaminants from waste into the phreatic surface and drainage.

2.2. Sampling. Soil samples were collected between September and October 2006 during the drilling of three monitoring wells. At every three meters of drilling, a representative sample of this range was taken.

Samples were bagged, labeled, and transported to the Companhia de Saneamento Ambiental do Distrito FederalCAESB Central Laboratory. Samples were harrowed by hand and submitted to air drying in a ventilated area. Once drying was complete, samples were quartered, and aliquots plus cross-check samples were submitted to analysis. Subsequently, the fraction of interest of granulometry less than or equal to $2 \mathrm{~mm}$ was separated.

Finally, samples of groundwater were collected using monitoring wells to assess water quality in the impacted area. Well locations are indicated in Table 1.
Groundwater samples were collected monthly from December 2006 to November 2007, using polyethylene samplers for each well. Well static level was measured before the collection of water samples, and a blank sample was taken to verify contaminations in the collected material.

2.3. Water Analysis. Water temperature, $\mathrm{pH}$ parameters, conductivity, and total dissolved solids (TDS) were measured in loco. Groundwater samples were stored refrigerated in polyethylene bottles (for chemical and physical analysis), in polyethylene bottles containing $1.5 \mathrm{~mL}$ of $\mathrm{HNO}_{3} / \mathrm{L}$ (for analysis of trace elements), and in sterilized glass bottles (for bacteriological analysis). Time between the first collection and the first analysis in the laboratory was always less than 4 hours. Analysis of turbidity, $\mathrm{Cl}^{-}, \mathrm{K}, \mathrm{Na}, \mathrm{Al}, \mathrm{Ca}$, nitrogen of nitrates $\left(\mathrm{NO}_{3}{ }^{-}\right)$, nitrogen of nitrites $\left(\mathrm{NO}_{2}{ }^{-}\right)$, ammoniacal nitrogen, free $\mathrm{CO}_{2}, \mathrm{SO}_{4}{ }^{2-}$, $\mathrm{Se}, \mathrm{Hg}, \mathrm{Sb}, \mathrm{Pb}, \mathrm{Ag}, \mathrm{Mg}, \mathrm{Fe}, \mathrm{As}$, $\mathrm{Ni}, \mathrm{Cd}, \mathrm{Cu}, \mathrm{Cr}, \mathrm{Mn}, \mathrm{Ba}, \mathrm{Co}, \mathrm{Zn}, \mathrm{Li}, \mathrm{P}, \mathrm{HCO}_{3}{ }^{-}, \mathrm{CO}_{3}{ }^{2-}$, total alkalinity, total hardness, consumed oxygen, $\mathrm{F}^{-}$, total coliforms, and thermotolerant coliforms of the samples were carried out in the laboratory [32].

2.4. Geophysical Methods. Significant deviations from the normal standard of geophysical measurements, which are the anomalies by the environmental standpoint, can indicate the presence of contaminants in the subsurface. This interpretation can indicate intensity of contamination, in order to provide important information for diagnostic activities, monitoring contaminants propagation and monitoring recovery of a degraded area.

The eletroresistivity method is one of the most used in environmental studies and is based on conduction of electric current in different materials. The method consists of setting four electrodes on the land surface, two current electrodes (A and B), and two potential electrodes ( $M$ and $\mathrm{N})$. An electric current is applied through the electrodes A and $\mathrm{B}$ on the ground and with the electrodes $\mathrm{M}$ and $\mathrm{N}$ the difference of potential associated with the electric current is measured. Knowing the applied current, the geometry of the electrodes arrangement, and the measured potential, it is possible to calculate the value of apparent electric resistivity [33]. Propagation of the electrical current in soils and rocks is caused by the displacement of dissolved ions in water contained in pores and cracks, being affected mainly by the mineralogical composition, porosity, water quantity, and the content and nature of dissolved salts. Among these factors, salinity, pore connectivity, temperature, and water quantity are the most important and represent a great potential for applications in environmental and hydrological studies, where the presence of water in the saturated zone and the increased concentration of contaminants can be investigated.

Metal stakes are usually employed as electrodes. There are different ways to arrange the electrodes in relation to each other, and to transport them on the ground to be studied. The Wenner array, designed by the North American Frank Wenner in 1915, is normally used for horizontal electrical profiling, which is characterized by the equidistant disposal of potential and current electrodes, according to a straight line [34-36]. The Schlumberger array, created by the french 
Conrad Schlumberger in $1912[35,36]$, is rather used for vertical electric sounding, which is the determination of the vertical variation of resistivity under a given point on the ground. In this array, the electrodes are distributed along a straight line, and the distance between the current electrodes $(\mathrm{AB})$ is higher than or equal to three-times the distance between the potential electrodes (MN) [35]. Both arrays can be used for surveys or profiling.

Five vertical electrical soundings in the gravel bed were carried out in May 2004. As a result, a high contrast between chemical sludge resistivity, laterite, and the local soil was observed, enabling the execution of new detailed surveys and subsequent drilling of research wells.

Two more geophysical surveys were conducted in the gravel pit for the research of the influence area of the chemical sludge after the success of the previous experiment. Two devices were used in this case: a resistivimeter model ER-300, manufactured by PERGEO, which allows applying voltages up to 500 volts to ground, used as a source of continuous current, and a millivoltmeter, manufactured by TECTROL, which measures voltages between 0 to $3,000 \mathrm{mV}$, and allows the compensation of soil natural potential.

In the first survey, performed on February 24 and 25, 2005 , a rectangular grid with $6 \times 10$ points spaced by 50 meters was established (Figure 1), and the electrical resistivity method was used with the Wenner array and a one meter spacing of the electrodes. In the second survey, carried out in August 2005, one of the lines of the previous study was chosen and corresponded to $1 \mathrm{D}, 2 \mathrm{D}, 3 \mathrm{D}, 4 \mathrm{D}, 5 \mathrm{D}$, $6 \mathrm{D}, 7 \mathrm{D}, 8 \mathrm{D}, 9 \mathrm{D}$ and $10 \mathrm{D}$ points (Figure 1 ). In this case, the eletroresistivity method with the Schlumberger arrangement for implementation of vertical electrical soundings was used. Data was processed in the Geophysical Laboratory of the Institute of Geosciences of the University of Brasilia-UNB.

2.5. Geochemical Methods. The fundamental geochemical characteristic of anthropogenic contaminant emissions is just the chemical imbalance, with the consequent existence of elements in the mobile phases.

Analytical procedures were performed in the Geochemistry Laboratory of the Institute of Geosciences, University of Brasilia and in the Central Laboratory of Information and Monitoring Unit of Water Resources-HIDROLAB/CAESB. To ensure reliability of data, samples of geochemical reference were analyzed in the same batch as that prepared for the study samples. Only parameters with concentration above the quantification limit and error below $10 \%$ relative to the reference samples values were accepted for evaluation.

Analyses of pH (soil: water); organic carbon; organic matter; cation exchange capacity (CEC); exchangeable $\mathrm{Al}^{3+}$, $\mathrm{Na}^{+}, \mathrm{K}^{+}, \mathrm{Ca}^{2+}$, and $\mathrm{Mg}^{2+}$; available $\mathrm{P}, \mathrm{Pb}, \mathrm{Zn}, \mathrm{Cu}$, and Mn; potential acidity $\left(\mathrm{H}^{+}+\mathrm{Al}^{3+}\right)$ was performed following EMBRAPA [37].

Determination of $\mathrm{Si}, \mathrm{Al}, \mathrm{Fe}, \mathrm{Ca}, \mathrm{Ti}, \mathrm{Sr}, \mathrm{Cu}, \mathrm{Zn}, \mathrm{Y}$, $\mathrm{Be}, \mathrm{Ba}, \mathrm{Co}, \mathrm{Ni}, \mathrm{Mn}, \mathrm{Cr}$, and $\mathrm{V}$ concentrations were made using optical emission spectrometer with inductively coupled plasma (ICP-OES) from Spectroanalytical Instruments GmbH brand, model Spectroflame FVM03, equipped with monochromator and polychromators in vacuum and air. For

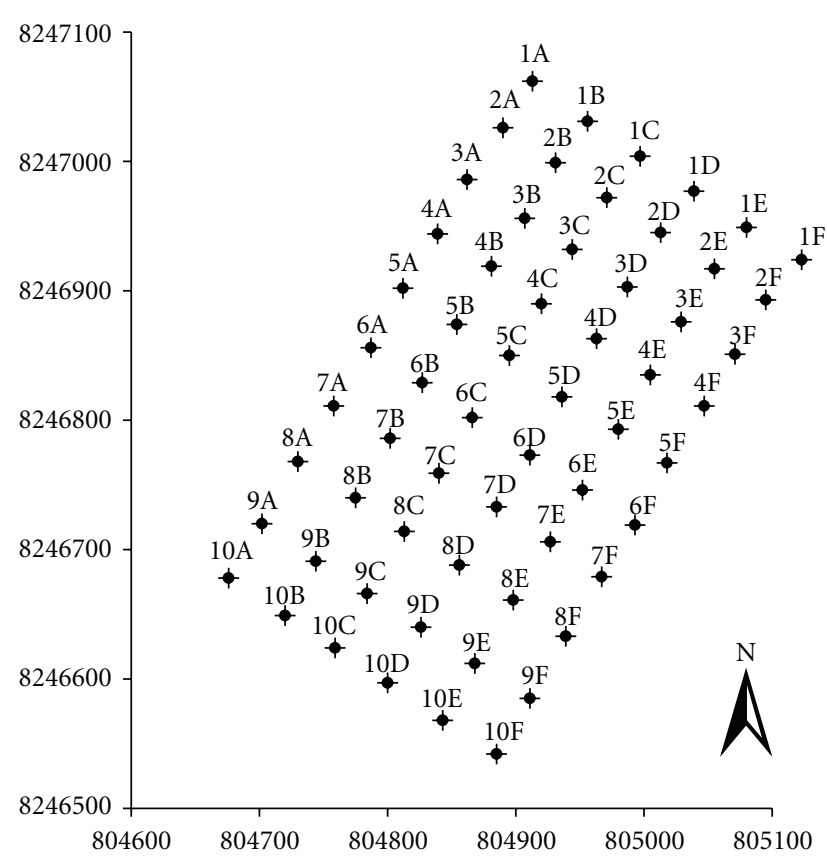

Figure 1: Location of the points of geophysical researches in the gravel pit. Datum: Astro Chuá.

this analysis, samples were prepared by acid decomposition with $\mathrm{HF} / \mathrm{HNO}_{3} / \mathrm{HClO}_{4} / \mathrm{HCl}$ or alkaline fusion, depending on the analyte [38]. Analyses by atomic absorption spectrometry with electrothermal source for the $\mathrm{Pb}$ element were processed with graphite furnace from GBC brand, model GF 3000, coupled with an atomic absorption spectrophotometer from GBC brand, model 932 AA.

All chemical analyses were performed using high purity water (resistivity of $18.2 \mathrm{M} \Omega \mathrm{cm}$ ) and reagents with analytical purity. The nitric acid was purified by subboiling process with a MARCONI quartz distiller, model MA-075.

2.6. Results Analysis. An element or a substance can be considered either a contaminant or an anomaly when it occurs in the environment with concentrations above levels considered as background or baseline. From the environmental viewpoint, a significant anomaly is associated with human intervention, whether direct or indirect. The anomalies are considered nonsignificant when it is caused by natural processes such as mineralization or other concentrations, provided that those do not present consequences from the environmental perspective [39]. Plume dispersion of a contaminant is the area affected by its occurrence and geochemical mobility.

The objective of grouping analysis is to gather elements of similar concentrations into groups, so elements belonging to the same group are similar to each other according to the measured variables, and elements in different groups are different in relation to the same measurements [40]. The Hierarchical Agglomerative Technique was used to group the data in samples of soil and water, according to the degree of "association or kinship". The method of the Hierarchical Tree, associated with the Ward Method, was also used 
adopting the Euclidean distance and normalization of the results for the $Z$-Score. This method allowed the analysis of quantitative $p$-variables, regardless of the multivariate normal distribution nature of the data [40]. Results were plotted as a dendrogram.

Previous studies have shown dispersion of chemicals in the gravel pit from the WTS disposal area [31]. Similarly, it was possible to choose suitable locations to install monitoring wells and to estimate, by interpolation, the concentration of various analytes at depths between 10 and $20 \mathrm{~cm}$ from the surface. These results were used in graphics relative to the vertical profiles.

To evaluate the degree of WTS influence in the disposal area, the index of geoaccumulation, $I_{\text {geo }}$, proposed by Müller [41], was modified. Obtained value allows us to classify levels of metal enrichment into seven classes, with progressive intensities of contamination.

This index is calculated using the formula:

$$
I_{\text {geo }}=\log 2\left(\frac{C_{N}}{1,5 C_{B}}\right),
$$

where $C_{N}=$ concentration of the element $\mathrm{n}$ in the sample to be classified, $C_{B}=$ average concentration of the element in the control area (upstream monitoring well), and 1,5 = correction factor for possible variations from the baseline caused by lithologic differences.

This index consists of seven distinct classes, ranging from 0 to 6 and is related to the increasing contamination level. The highest value corresponds to an enrichment of approximately 100-times compared to the reference level.

The determination of investigated depths in the geophysical methods is obtained by comparing data readings with theoretical models of the subsurface stratification. The software SOUNDER [42] and RES2DINV [43], provide a semiautomatic interpretation of the values of electric resistivity and were used in this study.

\section{Results and Discussion}

The first geophysical survey provided data for mapping the plume of the chemical sludge in the subsurface to a theoretical depth of $50 \mathrm{~cm}$ (Figure 2(a)).

The second survey enabled the evaluation of the WTS plume extension in the subsurface by measuring the electrical resistivity at various levels until reaching the theoretical depth of 4 meters (Figure 2(b)).

Geophysical surveys allowed mapping the WTS area of influence in the gravel pit horizontally and vertically. Results permitted to affirm that the sludge is a noninert waste, and that its disposal requires certain precautions, as recommended by the 2004 ABNT NBR 10.004 [44].

Average scores and standard deviations of the soil samples, chemical analysis obtained during the drilling of monitoring wells are listed in Table 2. Background levels were determined based on the average values and standard deviations of the samples from the upstream well (Table 2 and Figure 3). To enable comparison of these results with others in the literature, Table 2 was added to the benchmarks established by Schellmann [45] for shale and sandstones.

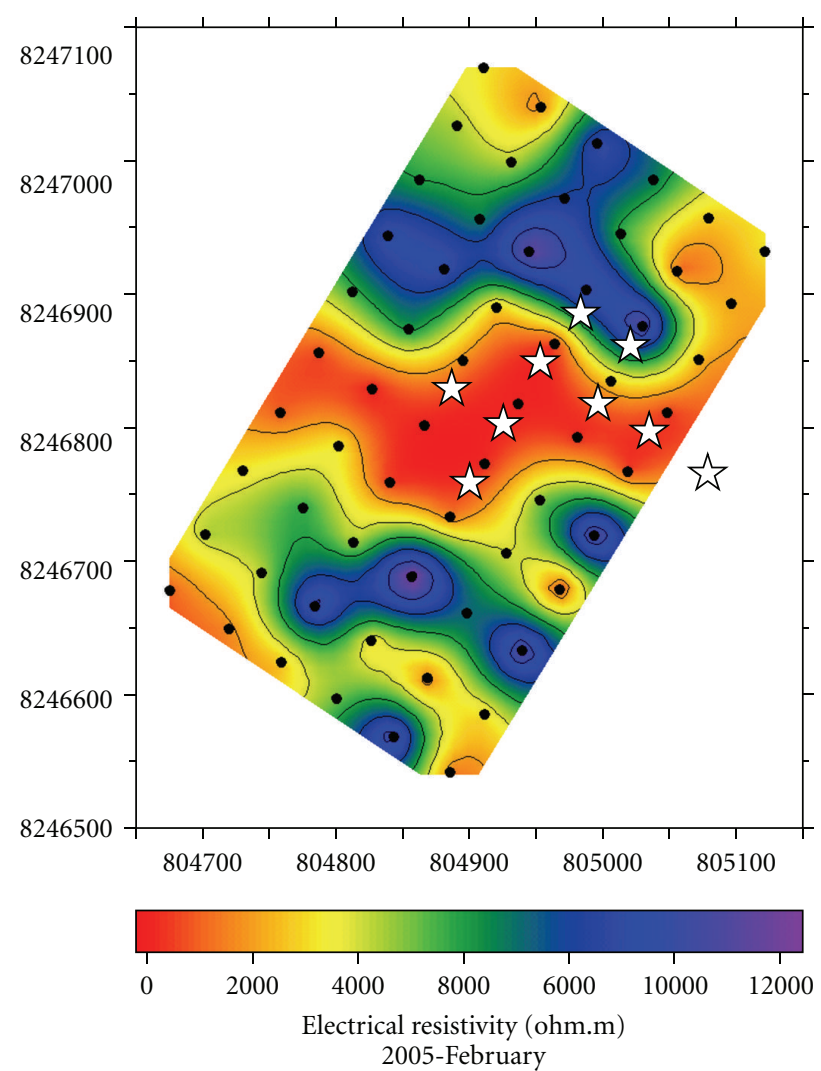

(a)

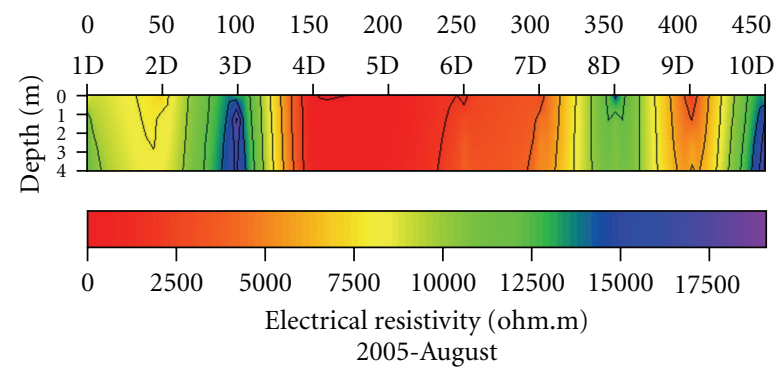

(b)

FIGURE 2: Geophysical surveys in the gravel pit. The central spots correspond to the plume resulting from the chemical sludge in the study area. (a) Horizontal mapping, highlights in white correspond to collection points located in the WTS disposal area. (b) Vertical electric sounding, especially emphasis is given to the area between 150 and 300 meters, where there is the sludge disposal. Graphic scales are different due to different times during data collection.

The hierarchical classification was calculated from the results of the major $(\mathrm{Si}, \mathrm{Al}, \mathrm{Fe}, \mathrm{Ti}$, and $\mathrm{K})$, minor $(\mathrm{Ca}$ and $\mathrm{Mg}$ ), and trace elements $(\mathrm{P}, \mathrm{Be}, \mathrm{Na}, \mathrm{Mn}, \mathrm{Co}, \mathrm{Cu}$, $\mathrm{Zn}, \mathrm{Ba}, \mathrm{Pb}, \mathrm{Sr}$, and $\mathrm{Y}$ ) analyses, besides the determination of CEC, free acidity, and $\mathrm{pH}$ of the soil samples taken during the drilling of the monitoring wells. By using the Hierarchical Tree Method, it was possible to separate horizons of each lateritic profile (Figure 4). Costa [46] established the behavioral patterns of elements content and the chemical compounds, when they were observed from 

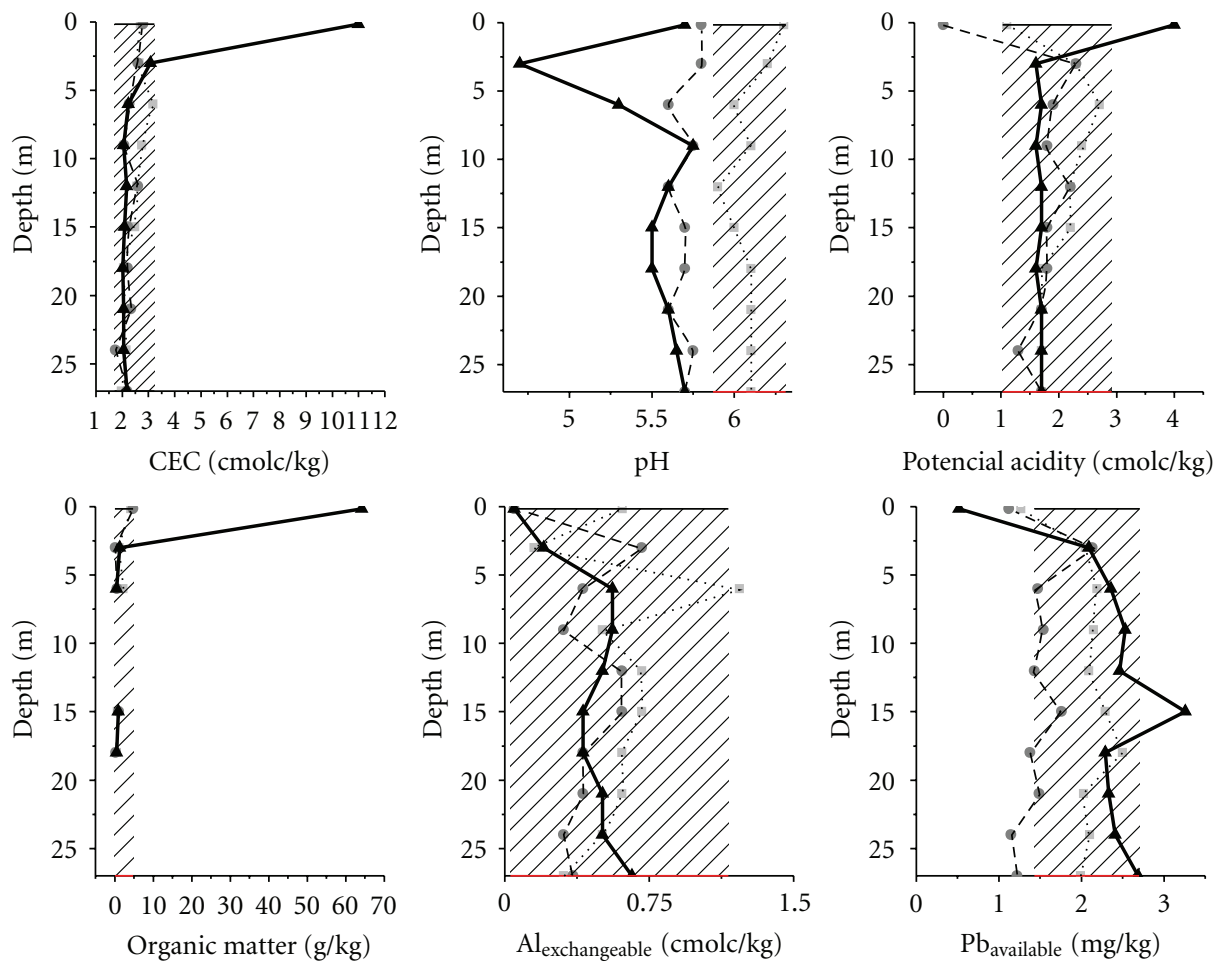

(a)
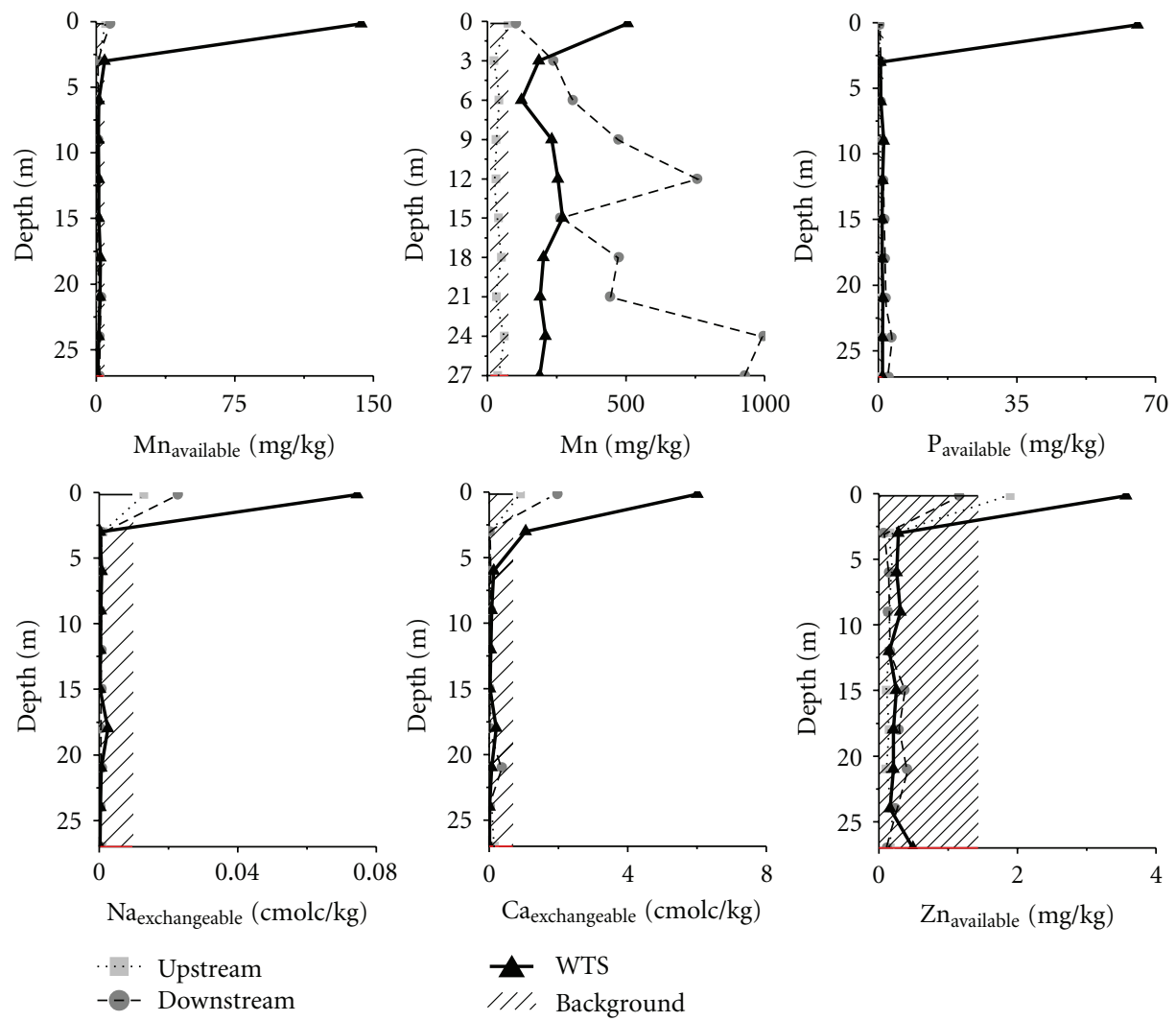

(b)

FIGURE 3: Vertical profiles of various parameters analyzed in samples obtained from monitoring well drillings. Highlighted bands on each graph correspond to background levels (range of two standard deviations of the samples average value from the control area-Upstream monitoring well). (a) Results of potential acidity, CEC, pH, organic matter, exchangeable-Al, and available- $\mathrm{Pb}$; (b) Results of Mn, available$\mathrm{Mn}$, available-P, available-Zn, exchangeable-Na, and exchangeable-Ca. 
TABLE 2: Results of the chemical analysis of samples taken every three meters from the drilling wells.

\begin{tabular}{|c|c|c|c|c|c|c|c|c|c|c|}
\hline \multirow[b]{2}{*}{ Parameters } & \multirow[b]{2}{*}{ Unit } & \multirow[b]{2}{*}{$\begin{array}{l}\text { Limit of } \\
\text { detection }\end{array}$} & \multicolumn{2}{|c|}{ Upstream well $(n=10)$} & \multicolumn{2}{|c|}{$\begin{array}{l}\text { Downstream well } \\
(n=10)\end{array}$} & \multicolumn{2}{|c|}{ WTS well $(n=10)$} & \multicolumn{2}{|c|}{$\begin{array}{c}\text { Schellmann } \\
\text { benchmarks (1980) }\end{array}$} \\
\hline & & & Average & $\begin{array}{l}\text { Standard } \\
\text { deviation }\end{array}$ & Average & $\begin{array}{l}\text { Standard } \\
\text { deviation }\end{array}$ & Average & $\begin{array}{l}\text { Standard } \\
\text { deviation }\end{array}$ & $\begin{array}{c}\text { Shale } \\
(n=74)\end{array}$ & $\begin{array}{c}\text { Sandstones } \\
(n=23)\end{array}$ \\
\hline Organic C & $\mathrm{mg} / \mathrm{kg}$ & 0.06 & 1,030 & 900 & 800 & 1130 & 7,830 & 16,420 & & \\
\hline $\begin{array}{l}\text { Organic } \\
\text { matter }\end{array}$ & $\mathrm{g} / \mathrm{kg}$ & 0.1 & 1.76 & 1.51 & 1.38 & 1.94 & 13.51 & 28.34 & & \\
\hline CEC & $\mathrm{cmolc} / \mathrm{kg}$ & 0.02 & 2.46 & 0.38 & 2.30 & 0.30 & 3.09 & 2.80 & & \\
\hline $\mathrm{Ca}_{\text {exchangeable }}$ & $\mathrm{cmolc} / \mathrm{kg}$ & 0.01 & 0.1311 & 0.2769 & 0.2551 & 0.6158 & 0.7648 & 1.8697 & & \\
\hline $\mathrm{Mg}_{\text {exchangeable }}$ & $\mathrm{cmolc} / \mathrm{kg}$ & 0.01 & 0.2692 & 0.1634 & 0.2976 & 0.1720 & 0.3288 & 0.1708 & & \\
\hline $\mathrm{Na}_{\text {exchangeable }}$ & $\mathrm{cmolc} / \mathrm{kg}$ & 0.0004 & 0.0019 & 0.0039 & 0.0027 & 0.0071 & 0.0080 & 0.0234 & & \\
\hline $\mathrm{K}_{\text {exchangeable }}$ & $\mathrm{cmolc} / \mathrm{kg}$ & 0.0004 & 0.0916 & 0.0334 & 0.0953 & 0.0319 & 0.0882 & 0.0222 & & \\
\hline $\begin{array}{l}\text { Potential } \\
\text { acidity }\end{array}$ & $\mathrm{cmolc} / \mathrm{kg}$ & 0.05 & 1.97 & 0.47 & 1.65 & 0.64 & 1.90 & 0.74 & & \\
\hline $\mathrm{Al}_{\text {exchangeable }}$ & $\mathrm{cmolc} / \mathrm{kg}$ & 0.05 & 0.5944 & 0.2814 & 0.4165 & 0.1899 & 0.4368 & 0.1829 & & \\
\hline $\mathrm{pH}$ & & & 6.09 & 0.11 & 5.70 & 0.08 & 5.50 & 0.31 & & \\
\hline $\mathrm{Al}_{2} \mathrm{O}_{3}$ & $\begin{array}{c}\mathrm{mg} \text { of } \\
\mathrm{Al}_{2} \mathrm{O}_{3} / \mathrm{kg}\end{array}$ & 529 & 191,000 & 40,300 & 166,820 & 32,964 & 174,640 & 32,075 & 269,000 & 106,000 \\
\hline $\mathrm{CaO}$ & $\begin{array}{c}\mathrm{mg} \text { of } \\
\mathrm{CaO} / \mathrm{kg}\end{array}$ & 112 & 2,500 & 1,100 & 2,930 & 678 & 1,560 & 795 & 1,200 & 1,100 \\
\hline $\mathrm{TiO}_{2}$ & $\begin{array}{c}\mathrm{mg} \text { of } \\
\mathrm{TiO}_{2} / \mathrm{kg}\end{array}$ & 28 & 13,000 & 3,000 & 10,780 & 2,195 & 9,490 & 1,208 & 13,600 & 8,200 \\
\hline $\mathrm{Na}$ & $\mathrm{mg}$ of $\mathrm{Na} / \mathrm{kg}$ & 4 & 213 & 233 & 130 & 22 & 183 & 167 & 1,400 & 3,560 \\
\hline Mn & $\mathrm{mg}$ of $\mathrm{Mn} / \mathrm{kg}$ & 0.03 & 42.69 & 15.84 & 498.77 & 302.17 & 235.97 & 103.28 & 540 & 1,630 \\
\hline $\mathrm{Fe}_{2} \mathrm{O}_{3}$ & $\begin{array}{c}\mathrm{mg} \text { of } \\
\mathrm{Fe}_{2} \mathrm{O}_{3} / \mathrm{kg}\end{array}$ & 41 & 104,500 & 72,800 & 133,530 & 50,492 & 93,910 & 19,093 & 197,000 & 163,000 \\
\hline $\mathrm{SiO}_{2}$ & $\begin{array}{c}\mathrm{mg} \text { of } \\
\mathrm{SiO}_{2} / \mathrm{kg}\end{array}$ & 169 & 579,700 & 142,900 & 580,000 & 127,387 & 584,150 & 145,370 & 392,000 & 637,000 \\
\hline $\mathrm{MgO}$ & $\begin{array}{c}\mathrm{mg} \text { of } \\
\mathrm{MgO} / \mathrm{kg}\end{array}$ & 166 & 4,200 & 1,900 & 8,590 & 2,818 & 2,730 & 988 & 2,500 & 2,600 \\
\hline Co & $\mathrm{mg}$ of $\mathrm{Co} / \mathrm{kg}$ & 1.1 & 6.81 & 6.53 & 15.68 & 8.76 & 14.07 & 5.34 & 13 & 38 \\
\hline K & $\mathrm{mg}$ of $\mathrm{K} / \mathrm{kg}$ & 4 & 23,215 & 19,724 & 30,853 & 22,694 & 18,497 & 12,138 & 3,490 & 4,650 \\
\hline $\mathrm{Cu}$ & $\mathrm{mg}$ of $\mathrm{Cu} / \mathrm{kg}$ & 0.097 & 25.30 & 18.40 & 27.36 & 7.20 & 16.93 & 5.11 & 40 & 37 \\
\hline $\mathrm{Zn}$ & $\mathrm{mg}$ of $\mathrm{Zn} / \mathrm{kg}$ & 0.43 & 32.59 & 16.69 & 54.03 & 18.75 & 43.42 & 7.67 & 25 & 10 \\
\hline $\mathrm{Ba}$ & $\mathrm{mg}$ of $\mathrm{Ba} / \mathrm{kg}$ & 0.13 & 166.09 & 37.19 & 264.71 & 81.20 & 162.12 & 28.94 & 122 & 295 \\
\hline $\mathrm{Pb}$ & $\mathrm{mg}$ of $\mathrm{Pb} / \mathrm{kg}$ & 1 & 29.22 & 11.28 & 22.55 & 9.17 & 13.43 & 10.70 & 38 & 48 \\
\hline Y & $\mathrm{mg}$ of $\mathrm{Y} / \mathrm{kg}$ & 0.22 & 21.27 & 3.92 & 19.10 & 3.06 & 20.04 & 2.10 & 21 & 12 \\
\hline $\mathrm{Sr}$ & $\mathrm{mg}$ of $\mathrm{Sr} / \mathrm{kg}$ & 0.99 & 44.19 & 27.30 & 47.80 & 5.98 & 36.39 & 12.01 & 34 & 26 \\
\hline $\mathrm{P}_{\text {available }}$ & $\mathrm{mg}$ of $\mathrm{P} / \mathrm{kg}$ & 0.002 & 0.52 & 0.34 & 1.54 & 0.94 & 7.42 & 20.41 & & \\
\hline $\mathrm{Zn}_{\text {available }}$ & $\mathrm{mg}$ of $\mathrm{Zn} / \mathrm{kg}$ & 0.43 & 0.33 & 0.55 & 0.31 & 0.32 & 0.59 & 1.05 & & \\
\hline $\mathrm{Mn}_{\text {available }}$ & $\mathrm{mg}$ of $\mathrm{Mn} / \mathrm{kg}$ & 0.03 & 1.17 & 1.44 & 1.97 & 2.08 & 15.94 & 44.80 & & \\
\hline $\mathrm{Cu}_{\text {available }}$ & $\mathrm{mg}$ of $\mathrm{Cu} / \mathrm{kg}$ & 0.097 & 0.49 & 0.42 & 0.50 & 0.16 & 0.40 & 0.09 & & \\
\hline $\mathrm{Pb}_{\text {available }}$ & $\mathrm{mg}$ of $\mathrm{Pb} / \mathrm{kg}$ & 0.01 & 2.07 & 0.32 & 1.47 & 0.30 & 2.29 & 0.70 & & \\
\hline $\mathrm{Be}$ & mg of Be/kg & 0.74 & 1.40 & 0.45 & 2.30 & 0.55 & 2.12 & 0.53 & & \\
\hline $\mathrm{Mn}_{\text {available }} / \mathrm{Mn}$ & $\%$ & & 2.44 & 1.72 & 0.99 & 2.24 & 3.66 & 8.69 & & \\
\hline $\mathrm{Cu}_{\text {available }} / \mathrm{Cu}$ & $\%$ & & 2.68 & 2.93 & 1.99 & 0.95 & 2.55 & 1.00 & & \\
\hline $\mathrm{Pb}_{\text {available }} / \mathrm{Pb}$ & $\%$ & & 8.24 & 3.73 & 7.69 & 3.48 & 29.84 & 19.70 & & \\
\hline $\mathrm{Zn}_{\text {available }} / \mathrm{Zn}$ & $\%$ & & 0.88 & 0.97 & 0.70 & 0.76 & 1.47 & 2.71 & & \\
\hline
\end{tabular}



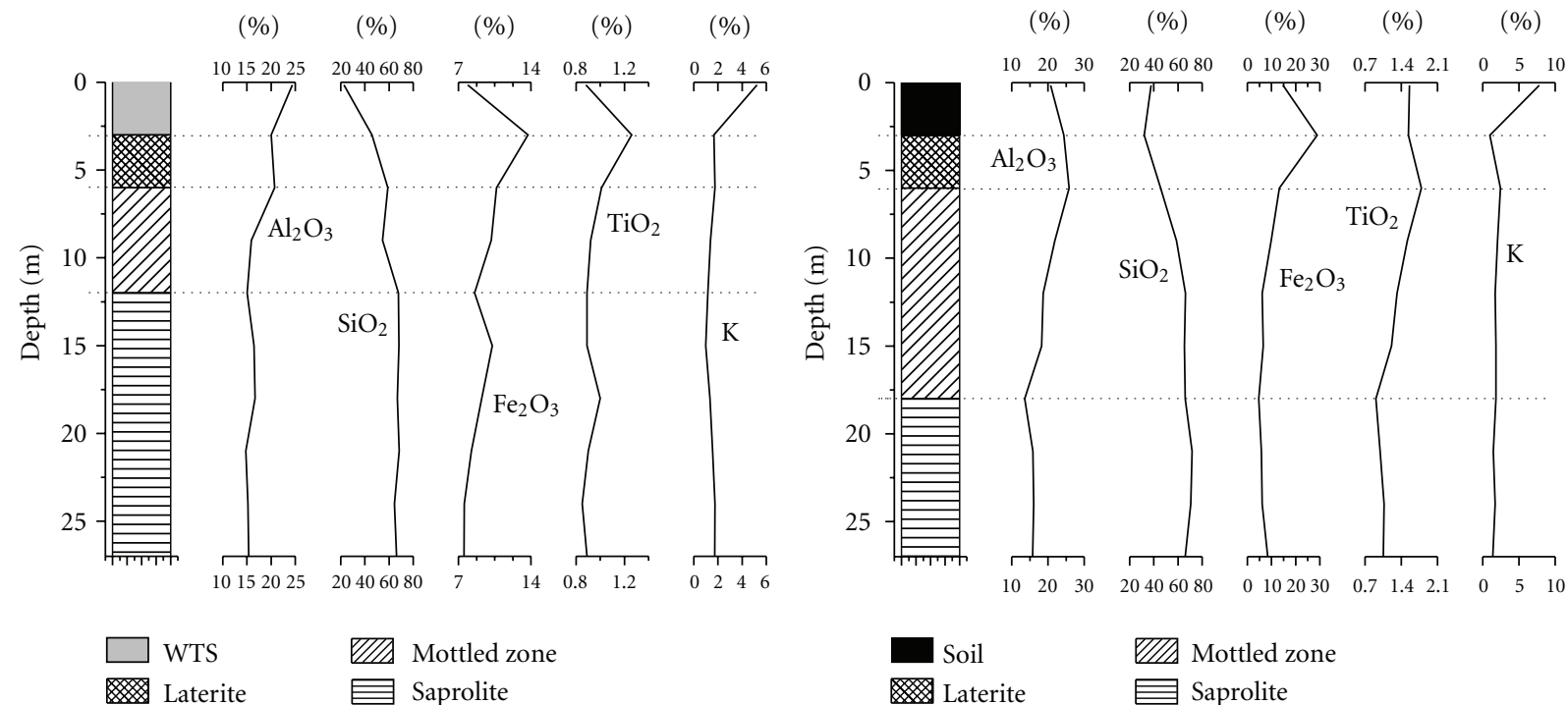

(a)

(b)

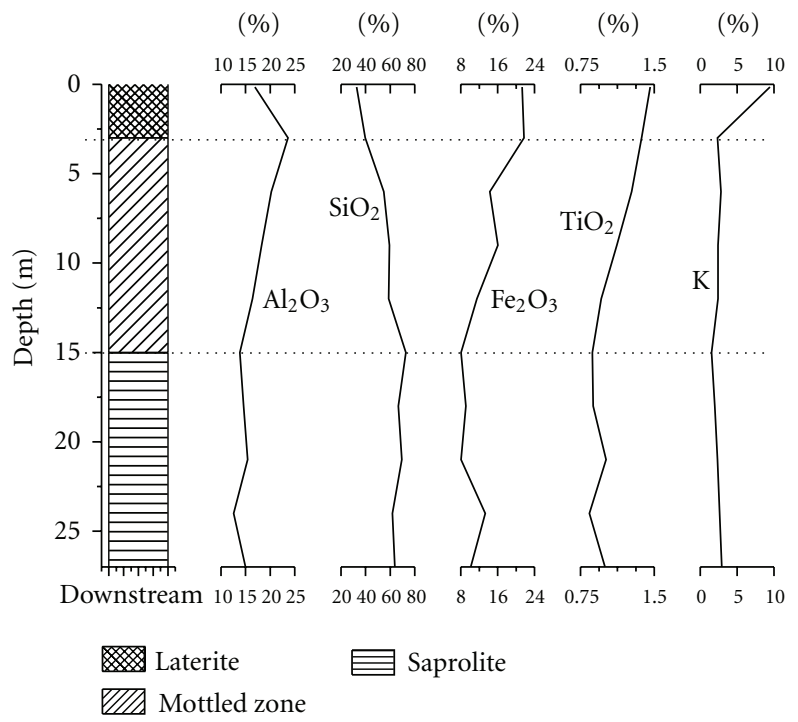

(c)

Figure 4: Hierarchical classification of samples extracted from the research well drillings. Analyses of major elements, mostly in the form of oxides, were placed in parallel to indicate the diagnostic horizons. (a) WTS well, (b) upstream well, and (c) downstream well.

bottom to top in a lateritic profile. Several of these patterns were identified in the study areas. Among them, the intense decrease (leaching) of $\mathrm{SiO}_{2}$ contents, the strong increase in $\mathrm{Fe}$ contents as oxy-hydroxides, the large increase in $\mathrm{Al}$ contents, the gradual increase in the concentrations of $\mathrm{Ti}$, the strong increase in $\mathrm{P}, \mathrm{Sr}, \mathrm{Ba}$ contents at the top of the profile, the strong growth only on the basis of the profile in $\mathrm{Mn}$ contents (this one most evident in the downstream monitoring well) were noted. These patterns were identified in all three profiles, although the sample taken in the upper portion of the WTS well has shown distinct characteristics in comparison with other horizons, indicating that changes in the composition are due from the chemical sludge deposited in the area. The standards set by Costa [46] corroborate the results obtained by the hierarchical classification, showing that this method may be considered appropriate for the evaluation of samples taken in the gravel pit.

According to the values obtained for the geoaccumulation indexes, parameters are classified into seven classes related to the degree of pollution, following Table 3. The geoaccumulation indexes showed that several samples from the WTS monitoring well presented results that can be considered from moderate to highly polluted (Table 4).

The average scores and the standard deviations of soil samples chemical analysis obtained by the drilling of research wells are listed in Table 2. Background levels were determined from the average values and the standard deviations of samples from the upstream monitoring well (Table 2 and Figure 3). To enable comparison of these results with others 
TABLE 3: Classification of the parameters by the geoaccumulation index, according to the degree of pollution.

\begin{tabular}{lcc}
\hline Classification & Class of $I_{\text {geo }}$ & $I_{\text {geo }}$ \\
\hline Extremely polluted & 6 & $>5$ \\
Heavily to extremely polluted & 5 & $>4$ a 5 \\
Heavily polluted & 4 & $>3$ a 4 \\
Moderately to heavily polluted & 3 & $>2$ a 3 \\
Moderately polluted & 2 & $>1$ a 2 \\
Unpolluted to moderately polluted & 1 & $>0$ a 1 \\
Practically unpolluted & 0 & $<0$ \\
\hline
\end{tabular}

in the literature, the benchmarks established by Schellmann [45] for shale and sandstones were added to Table 2.

In Figure 3, it is possible to note the extension of these changes over the lateritic profiles when comparing measured values with those obtained in the control area (upstream monitoring well). In the WTS disposal area, near the ground surface, positive significant anomalies of $\mathrm{Mn}$, available-Mn, CEC, potential acidity, available-P, exchangeable-Ca, organic matter, and exchangeable- $\mathrm{Na}$ were identified besides lower $\mathrm{pH}$ than the basic level. The available- $\mathrm{Pb}$ was considered anomalous both in low concentrations (depth of $0.15 \mathrm{~m}$ ) and in high concentrations (depth of $15 \mathrm{~m}$ ). However, the influence of sludge is drastically reduced to $3 \mathrm{~m}$ and practically disappears in other investigated depths (Figures 3 and 4).

R. C. A. Moreira et al. [31] compared the WTS disposal area with surrounding areas and noted the presence of gibbsite and kaolinite minerals. Despite the predominance of these minerals, which have aluminum in their composition, the concentrations of exchangeable-Al were considered low. They also observed that the CEC was high compared to the adjacent areas, had low availability of $\mathrm{Pb}$ and high concentration of organic matter and some chemical elements such as $\mathrm{Ca}, \mathrm{Cu}, \mathrm{Al}$ and $\mathrm{Mn}$, as well as the available elements $\mathrm{Ca}, \mathrm{Zn}, \mathrm{P}$, and $\mathrm{Mn}$. The low mobility of cationic metals in the soil can be assigned to the formation of innersphere complexes (specific adsorption) with minerals [47]. This behavior is well known in the case of $\mathrm{Pb}$, and this interaction tends to become increasingly strong with time, making the bioavailability of this element gradually reduced. Even under low $\mathrm{pH}$ and high potential acidity, low contents of exchangeable-Al may be linked to physicochemical interactions of $\mathrm{Al}$ with organic matter and soil minerals, creating conditions for the complexation of $\mathrm{Al}$, transforming this element in a less toxic form to the plants [48]. Previous studies have found already that contents of saturation for Al in WTS from Rio Descoberto WTP were indeed very low [19]. The available-Mn in WTS was originated in the ferric aluminum sulphate coagulant [31]. The ratio between the concentration of available-Mn and total Mn was the highest in the WTS disposal area and indicated that sludge showed high percentages of Mn exactly in the form most easily assimilated by plants. Thus, the WTS disposal in the gravel pit has contributed significantly not only to the increasing concentration of $\mathrm{Mn}$ in the soil, but also with the increase in mobility of this element.

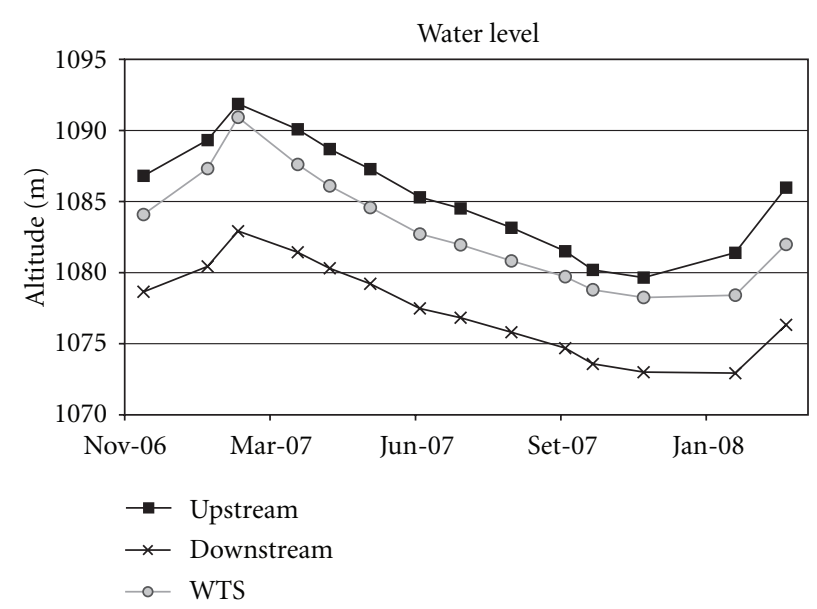

FIGURE 5: Variation of water levels measured in monitoring wells.

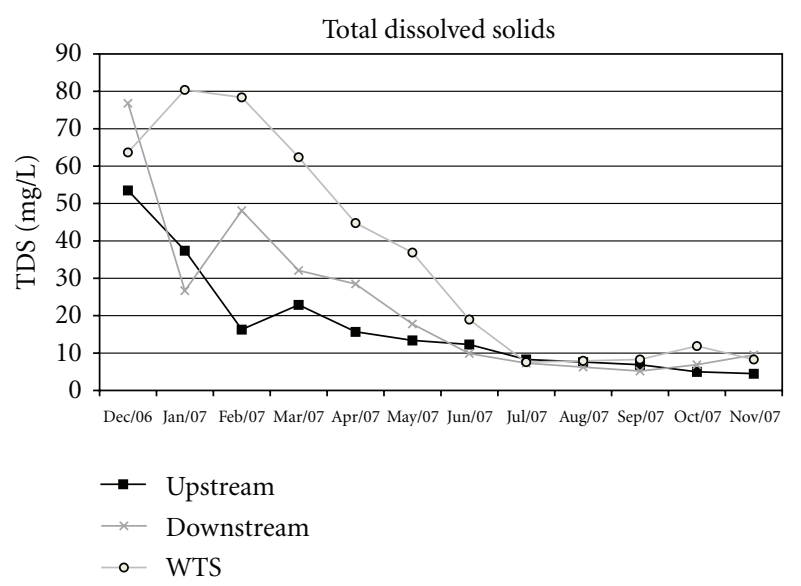

FIGURE 6: Monthly variation of TDS concentrations of the monitoring wells.

Similarly, the high levels of organic matter in this area can be considered positive, since it favored the improvement of soil structure. This is a preponderant factor for the recovery of gravel pits through revegetation [49].

Measurements of water levels from inspection wells, from December 2006 to February 2008, showed that the phreatic surface varies seasonally (Figure 5 ). The TDS in the monitoring wells was analyzed in the inspection wells from December 2006 to November 2007, and a seasonal variation in the concentrations of these solids was also found (Figure 6). The elevation of phreatic surface favored leaching of chemicals in the metarrythmites, increasing the concentration of TDS in the samples.

Santos et al. [50] classified the main aquifers exploited in the Distrito Federal for public supply through diagrams of the most abundant ions and also for hierarchical classifications. The wells located on the R4 Subsystem showed bicarbonated calcium or sodium character, depending on the variations of the lithologies that compose these aquifers. The $\mathrm{pH}$ showed wide variation (from 5.5 to 7.5 ), as well 
TABLE 4: Geoaccumulation indexes obtained in soil samples from the WTS monitoring well.

\begin{tabular}{|c|c|c|c|c|c|c|c|}
\hline \multirow{2}{*}{$\begin{array}{l}\text { Depth } \\
(\mathrm{m})\end{array}$} & \multicolumn{7}{|c|}{$I_{\text {geo }}$ Class } \\
\hline & 0 & 1 & 2 & 3 & 4 & 5 & 6 \\
\hline 0,15 & $\begin{array}{c}\mathrm{SiO}_{2}, \mathrm{Al}_{\mathrm{ex}}, \mathrm{Al}_{2} \mathrm{O}_{3}, \mathrm{TiO}_{2}, \mathrm{CaO}, \mathrm{MgO}, \mathrm{Fe}_{2} \mathrm{O}_{3} \\
\mathrm{Sr}, \mathrm{Cu}, \mathrm{Y}, \mathrm{Ba}, \mathrm{Pb}, \mathrm{Pb}_{\mathrm{av}}, \mathrm{Cu}_{\mathrm{av}}, \mathrm{Zn}, \mathrm{Be}, \mathrm{Co}\end{array}$ & $\mathrm{Mg}_{\mathrm{ex}}, \mathrm{K}_{\mathrm{ex}}, \mathrm{K}, \mathrm{Na}$ & CEC & $\mathrm{Mn}, \mathrm{Zn}_{\mathrm{av}}$ & & $\mathrm{MO}, \mathrm{Ca}_{\mathrm{ex}}, \mathrm{Na}_{\mathrm{ex}}$ & $\mathrm{Mn}_{\mathrm{av}}, \mathrm{P}_{\mathrm{av}}$ \\
\hline 3 & $\begin{array}{c}\mathrm{SiO}_{2}, \mathrm{Al}_{\mathrm{ex}}, \mathrm{Al}_{2} \mathrm{O}_{3}, \mathrm{TiO}_{2}, \mathrm{CaO}, \mathrm{MgO}, \mathrm{Fe}_{2} \mathrm{O}_{3} \\
\mathrm{Sr}, \mathrm{Cu}, \mathrm{Y}, \mathrm{Ba}, \mathrm{Pb}, \mathrm{Pb}_{\mathrm{av}}, \mathrm{Cu}_{\mathrm{av}}, \mathrm{MO}, \mathrm{Mg}_{\mathrm{ex}} \\
\mathrm{Na}_{\mathrm{ex}}, \mathrm{K}_{\mathrm{ex}}, \mathrm{CEC}, \mathrm{Na}, \mathrm{K}, \mathrm{Zn}_{\mathrm{av}}, \mathrm{P}_{\mathrm{av}}, \mathrm{Zn} \\
\end{array}$ & $\mathrm{Be}, \mathrm{Co}$ & $\mathrm{Mn}_{\mathrm{av}}, \mathrm{Mn}$ & $\mathrm{Ca}_{\mathrm{ex}}$ & & & \\
\hline 6 & $\begin{array}{c}\mathrm{SiO}_{2}, \mathrm{Al}_{\mathrm{ex}}, \mathrm{Al}_{2} \mathrm{O}_{3}, \mathrm{TiO}_{2}, \mathrm{CaO}, \mathrm{MgO}, \mathrm{Fe}_{2} \mathrm{O}_{3} \\
\mathrm{Sr}, \mathrm{Cu}, \mathrm{Y}, \mathrm{Ba}, \mathrm{Pb}, \mathrm{Pb}_{\mathrm{av}}, \mathrm{Cu}_{\mathrm{av}}, \mathrm{MO}, \mathrm{Ca}_{\mathrm{ex}} \\
\mathrm{Mg}_{\mathrm{ex}}, \mathrm{Na}_{\mathrm{ex}}, \mathrm{K}_{\mathrm{ex}}, \mathrm{CEC}, \mathrm{Na}, \mathrm{K}, \mathrm{Mn}_{\mathrm{av}}, \mathrm{Zn}_{\mathrm{av}} \\
\mathrm{P}_{\mathrm{av}}, \mathrm{Zn}, \mathrm{Be}\end{array}$ & $\mathrm{Mn}, \mathrm{Co}$ & & & & & \\
\hline 9 & $\begin{array}{c}\mathrm{SiO}_{2}, \mathrm{Al}_{\mathrm{ex}}, \mathrm{Al}_{2} \mathrm{O}_{3}, \mathrm{TiO}_{2}, \mathrm{CaO}, \mathrm{MgO}, \mathrm{Fe}_{2} \mathrm{O}_{3} \\
\mathrm{Sr}, \mathrm{Cu}, \mathrm{Y}, \mathrm{Ba}, \mathrm{Pb}, \mathrm{Pb}_{\mathrm{av}}, \mathrm{Cu}_{\mathrm{av}}, \mathrm{Ca}_{\mathrm{ex}}, \mathrm{Mg}_{\mathrm{ex}} \\
\mathrm{Na}_{\mathrm{ex}}, \mathrm{K}_{\mathrm{ex}}, \mathrm{CEC}, \mathrm{Na}, \mathrm{K}, \mathrm{Mn}_{\mathrm{av}}, \mathrm{Zn}_{\mathrm{av}} \\
\end{array}$ & $\mathrm{P}_{\mathrm{av}}, \mathrm{Zn}, \mathrm{Be}, \mathrm{Co}$ & $\mathrm{Mn}$ & & & & \\
\hline 12 & $\begin{array}{c}\mathrm{SiO}{ }_{2}, \mathrm{Al}_{\mathrm{ex}}, \mathrm{Al}_{2} \mathrm{O}_{3}, \mathrm{TiO}_{2}, \mathrm{CaO}, \mathrm{MgO}, \mathrm{Fe}_{2} \mathrm{O}_{3} \\
\mathrm{Sr}, \mathrm{Cu}, \mathrm{Y}, \mathrm{Ba}, \mathrm{Pb}, \mathrm{Pb}_{\mathrm{av}}, \mathrm{Cu}_{\mathrm{av}}, \mathrm{Ca}_{\mathrm{ex}}, \mathrm{Mg}_{\mathrm{ex}} \\
\mathrm{Na}_{\mathrm{ex}}, \mathrm{K}_{\mathrm{ex}}, \mathrm{CEC}, \mathrm{Na}, \mathrm{K}, \mathrm{Mn}_{\mathrm{av}}, \mathrm{Zn}_{\mathrm{av}} \\
\end{array}$ & $\mathrm{P}_{\mathrm{av}}, \mathrm{Zn}, \mathrm{Be}, \mathrm{Co}$ & $\mathrm{Mn}$ & & & & \\
\hline 15 & $\begin{array}{c}\mathrm{SiO}_{2}, \mathrm{Al}_{\mathrm{ex}}, \mathrm{Al}_{2} \mathrm{O}_{3}, \mathrm{TiO}_{2}, \mathrm{CaO}, \mathrm{MgO}, \mathrm{Fe}_{2} \mathrm{O}_{3} \\
\mathrm{Sr}, \mathrm{Cu}, \mathrm{Y}, \mathrm{Ba}, \mathrm{Pb}, \mathrm{Cu}_{\mathrm{av}} \mathrm{MO}, \mathrm{Ca}_{\mathrm{ex}}, \mathrm{Mg}_{\mathrm{ex}} \\
\mathrm{Na}_{\mathrm{ex}}, \mathrm{K}_{\mathrm{ex}}, \mathrm{CEC}, \mathrm{Na}, \mathrm{K}, \mathrm{Mn}_{\mathrm{av}}, \mathrm{Zn}_{\mathrm{av}} \\
\end{array}$ & $\mathrm{P}_{\mathrm{av}}, \mathrm{Pb}_{\mathrm{av}}, \mathrm{Zn}, \mathrm{Be}, \mathrm{Co}$ & & $\mathrm{Mn}$ & & & \\
\hline 18 & $\begin{array}{c}\mathrm{SiO}_{2}, \mathrm{Al}_{\mathrm{ex}}, \mathrm{Al}_{2} \mathrm{O}_{3}, \mathrm{TiO}_{2}, \mathrm{CaO}, \mathrm{MgO}, \mathrm{Fe}_{2} \mathrm{O}_{3} \\
\mathrm{Sr}, \mathrm{Cu}, \mathrm{Y}, \mathrm{Ba}, \mathrm{Pb}, \mathrm{Pb}_{\mathrm{av}}, \mathrm{Cu}_{\mathrm{av}}, \mathrm{MO}, \mathrm{Mg}_{\mathrm{ex}} \\
\mathrm{Na}_{\mathrm{ex}}, \mathrm{K}_{\mathrm{ex}}, \mathrm{CEC}, \mathrm{Na}, \mathrm{K}, \mathrm{Mn}_{\mathrm{av}}, \mathrm{Zn}_{\mathrm{av}}, \mathrm{Zn}, \mathrm{Be}\end{array}$ & $\mathrm{Ca}_{\mathrm{ex}}, \mathrm{P}_{\mathrm{av}}, \mathrm{Co}$ & $\mathrm{Mn}$ & & & & \\
\hline 21 & $\begin{array}{c}\mathrm{SiO}_{2}, \mathrm{Al}_{\mathrm{ex}}, \mathrm{Al}_{2} \mathrm{O}_{3}, \mathrm{TiO}_{2}, \mathrm{CaO}, \mathrm{MgO}, \mathrm{Fe}_{2} \mathrm{O}_{3} \\
\mathrm{Sr}, \mathrm{Cu}, \mathrm{Y}, \mathrm{Ba}, \mathrm{Pb}, \mathrm{Pb}_{\mathrm{av}}, \mathrm{Cu}_{\mathrm{av}}, \mathrm{Ca}_{\mathrm{ex}}, \mathrm{Mg}_{\mathrm{ex}} \\
\mathrm{Na}_{\mathrm{ex}}, \mathrm{K}_{\mathrm{ex}}, \mathrm{CEC}, \mathrm{Na}, \mathrm{K}, \mathrm{Mn}_{\mathrm{av}}, \mathrm{Zn}_{\mathrm{av}}, \mathrm{Zn} \\
\end{array}$ & $\mathrm{P}_{\mathrm{av}}, \mathrm{Be}, \mathrm{Co}$ & $\mathrm{Mn}$ & & & & \\
\hline 24 & $\begin{array}{c}\mathrm{SiO}_{2}, \mathrm{Al}_{\mathrm{ex}}, \mathrm{Al}_{2} \mathrm{O}_{3}, \mathrm{TiO}_{2}, \mathrm{CaO}, \mathrm{MgO}, \mathrm{Fe}_{2} \mathrm{O}_{3} \\
\mathrm{Sr}, \mathrm{Cu}, \mathrm{Y}, \mathrm{Ba}, \mathrm{Pb}, \mathrm{Pb}_{\mathrm{av}}, \mathrm{Cu}_{\mathrm{av}}, \mathrm{Ca}_{\mathrm{ex}}, \mathrm{Mg}_{\mathrm{ex}} \\
\mathrm{Na}_{\mathrm{ex}}, \mathrm{K}_{\mathrm{ex}}, \mathrm{CEC}, \mathrm{Na}, \mathrm{K}, \mathrm{Mn}_{\mathrm{av}}, \mathrm{Zn}_{\mathrm{av}}, \mathrm{Zn} \\
\end{array}$ & $\mathrm{P}_{\mathrm{av}}, \mathrm{Be}, \mathrm{Co}$ & $\mathrm{Mn}$ & & & & \\
\hline 27 & $\begin{array}{c}\mathrm{SiO}_{2}, \mathrm{Al}_{\mathrm{ex}}, \mathrm{Al}_{2} \mathrm{O}_{3}, \mathrm{TiO}_{2}, \mathrm{CaO}, \mathrm{MgO}, \mathrm{Fe}_{2} \mathrm{O}_{3} \\
\mathrm{Sr}, \mathrm{Cu}, \mathrm{Y}, \mathrm{Ba}, \mathrm{Pb}, \mathrm{Pb}_{\mathrm{av}}, \mathrm{Cu}_{\mathrm{av}}, \mathrm{Ca}_{\mathrm{ex}}, \mathrm{Mg}_{\mathrm{ex}} \\
\mathrm{Na}_{\mathrm{ex}}, \mathrm{K}_{\mathrm{ex}}, \mathrm{CEC}, \mathrm{Na}, \mathrm{K}, \mathrm{Mn}_{\mathrm{av}}, \mathrm{Zn}, \mathrm{Be}, \mathrm{Co}\end{array}$ & $\mathrm{Zn}_{\mathrm{av}}, \mathrm{P}_{\mathrm{av}}$ & $\mathrm{Mn}$ & & & & \\
\hline
\end{tabular}

as the electrical conductivity (from 6 to $90 \mu \mathrm{S} \cdot \mathrm{cm}^{-1}$ ) and water hardness (between 20 and $40 \mathrm{mg}$ of $\mathrm{CaCO}_{3} \cdot \mathrm{L}^{-1}$ ).

The gravel pit monitoring wells showed similar results to those found by Santos et al. [50], although in some samples, especially in the second half of 2007, the results were lower than those reported in all wells. In general, groundwater samples showed weak mineralization (trace mineral waters), with average concentrations of TDS ranging between 21.5 and $36.7 \mathrm{mg} / \mathrm{L}$ (Table 5 ). The waters of monitoring wells have calcium and/or magnesium bicarbonated facies (Figure 7).

Boaventura and Freitas [51] established inorganic indicators of groundwater quality in the Distrito Federal territory. In the forty deep wells investigated, $\mathrm{pH}$, conductivity, total dissolved solids, $\mathrm{Na}, \mathrm{K}, \mathrm{Ca}, \mathrm{Mg}, \mathrm{Fe}, \mathrm{Al}, \mathrm{Cu}, \mathrm{Cd}, \mathrm{Cr}, \mathrm{Mn}$, and $\mathrm{Zn}$ parameters were analyzed. Low conductivity, $\mathrm{pH}$ less than 5 , and concentration of $\mathrm{Na}, \mathrm{K}$, and Ca below $0.45 \mathrm{mg} / \mathrm{L}$ were considered as characteristic of samples less disturbed by human activities. Concentrations of trace elements tend to be low, an increase of conductivity can be understood as the first sign of change in water quality. Anomalies of $\mathrm{Na}$, $\mathrm{Cl}^{-}$, and $\mathrm{NO}_{3}^{-}$were related to the sewage dilution as well as high concentration values of $\mathrm{Al}$ and $\mathrm{Cu}$ associated with the alkalinity and water $\mathrm{pH}$ greater than 5 .

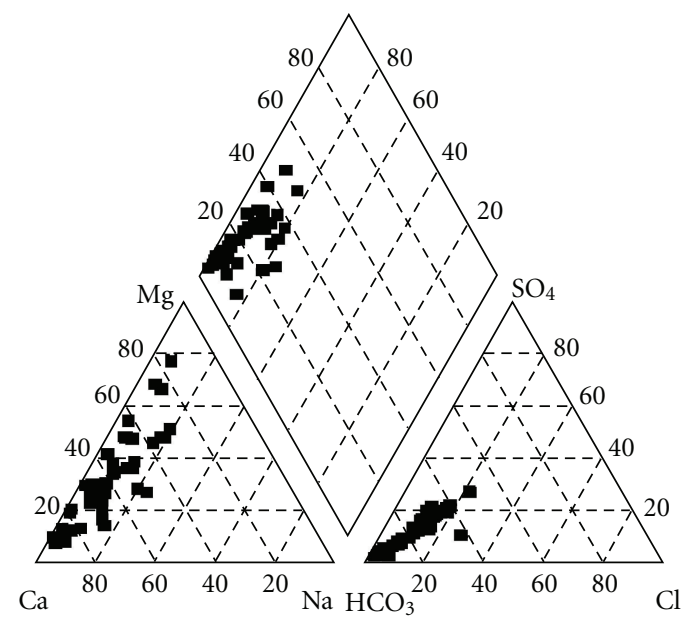

Figure 7: Piper diagrams relating to the samples of water from research wells.

From these characteristics, no changes were noted regarding concentration of $\mathrm{Na}, \mathrm{Cl}^{-}, \mathrm{NO}_{3}^{-}$, and $\mathrm{K}$. However, the WTS disposal area showed small elevation of $\mathrm{pH}$, caused 
TABLE 5: Results of water analysis.

\begin{tabular}{|c|c|c|c|c|c|c|c|c|}
\hline \multirow{2}{*}{ Parameters } & \multirow{2}{*}{ Unit } & \multicolumn{2}{|c|}{ Upstream well $(n=12)$} & \multicolumn{2}{|c|}{ Downstream well $(n=12)$} & \multicolumn{2}{|c|}{ WTS well $(n=12)$} & \multirow{2}{*}{ L. D. } \\
\hline & & Average & Standard deviation & Average & Standard deviation & Average & Standard deviation & \\
\hline Depth & $\mathrm{m}$ & 15.59 & 3.85 & 18.60 & 3.22 & 17.91 & 3.87 & \\
\hline $\mathrm{pH}$ & & 5.3 & 0.5 & 5.4 & 0.5 & 5.8 & 0.5 & \\
\hline Conductivity & $\mu \mathrm{S} / \mathrm{cm}$ & 31.7 & 24.2 & 33.0 & 18.3 & 54.0 & 29.2 & \\
\hline TDS & $\mathrm{mg} / \mathrm{L}$ & 21.5 & 16.4 & 22.4 & 12.5 & 36.7 & 19.9 & \\
\hline Hardness & $\mathrm{mg} \mathrm{CaCO} 3 / \mathrm{L}$ & 7.5 & 5.3 & 11.7 & 8.2 & 18.5 & 15.8 & \\
\hline Total alkalinity & $\mathrm{mg} \mathrm{CaCO} 3 / \mathrm{L}$ & 6.0 & 4.5 & 8.2 & 7.0 & 16.1 & 14.4 & \\
\hline Turbidity & NTU & 52.0 & 91.2 & 365.4 & $1,105.8$ & 10.1 & 11.2 & 0.1 \\
\hline Consumed oxygen & $\mathrm{mg} / \mathrm{L}$ & 2.4 & 1.1 & 3.4 & 1.9 & 2.9 & 1.3 & \\
\hline $\mathrm{Na}$ & $\mathrm{mg} / \mathrm{L}$ & 0.5 & 0.3 & 0.4 & 0.5 & 0.4 & 0.4 & 0.01 \\
\hline K & $\mathrm{mg} / \mathrm{L}$ & 0.3 & 0.1 & 0.4 & 0.2 & 0.3 & 0.1 & 0.01 \\
\hline $\mathrm{Mg}$ & $\mathrm{mg} / \mathrm{L}$ & 0.7 & 0.5 & 0.9 & 0.4 & 1.0 & 0.5 & 0.0 \\
\hline $\mathrm{Ca}$ & $\mathrm{mg} / \mathrm{L}$ & 1.8 & 1.8 & 3.2 & 3.1 & 5.8 & 5.7 & 0.02 \\
\hline $\mathrm{Mn}$ & $\mathrm{mg} / \mathrm{L}$ & 0.033 & 0.019 & 0.039 & 0.013 & 0.027 & 0.005 & 0.015 \\
\hline $\mathrm{Fe}$ & $\mathrm{mg} / \mathrm{L}$ & 0.268 & 0.236 & 1.371 & 3.946 & 0.185 & 0.103 & 0.010 \\
\hline Ammonia nitrogen & $\mathrm{mg} / \mathrm{L}$ & 0.029 & 0.021 & 0.039 & 0.050 & 0.034 & 0.038 & 0.020 \\
\hline $\mathrm{Ba}$ & $\mathrm{mg} / \mathrm{L}$ & 0.009 & 0.008 & 0.023 & 0.019 & 0.021 & 0.018 & 0.003 \\
\hline $\mathrm{Zn}$ & $\mathrm{mg} / \mathrm{L}$ & 0.041 & 0.026 & 0.029 & 0.010 & 0.036 & 0.017 & 0.012 \\
\hline $\mathrm{Cu}$ & $\mathrm{mg} / \mathrm{L}$ & 0.004 & 0.003 & 0.004 & 0.002 & 0.018 & 0.049 & 0.001 \\
\hline $\mathrm{Cl}$ & $\mathrm{mg} / \mathrm{L}$ & 0.7 & 0.4 & 0.7 & 0.2 & 0.8 & 0.5 & 0.1 \\
\hline $\mathrm{SO}_{4}^{2-}$ & $\mathrm{mg} / \mathrm{L}$ & L 1.0 & - & L 1.0 & - & L 1.0 & - & 1.0 \\
\hline $\mathrm{NO}_{3}^{-}$ & $\mathrm{mg} / \mathrm{L}$ & 0.125 & 0.064 & 0.273 & 0.152 & 0.052 & 0.033 & 0.010 \\
\hline $\mathrm{HCO}_{3}^{-}$ & $\mathrm{mg} / \mathrm{L}$ & 7.27 & 5.55 & 10.83 & 8.40 & 19.68 & 17.52 & \\
\hline $\mathrm{Al}$ & $\mathrm{mg} / \mathrm{L}$ & 0.704 & 1.291 & 0.396 & 0.417 & 0.268 & 0.200 & 0.002 \\
\hline $\mathrm{P}$ & $\mathrm{mg} / \mathrm{L}$ & 0.032 & 0.018 & 0.083 & 0.067 & 0.051 & 0.037 & 0.002 \\
\hline Free $\mathrm{CO}_{2}$ & $\mathrm{mg} / \mathrm{L}$ & 46.75 & 26.12 & 63.60 & 67.06 & 36.22 & 18.36 & \\
\hline $\mathrm{Pb}$ & $\mathrm{mg} / \mathrm{L}$ & 0.194 & 0.136 & 0.170 & 0.115 & 0.297 & 0.169 & 0.004 \\
\hline Thermotolerant coliforms & $\mathrm{MPN} / 100 \mathrm{~mL}$ & Abs. & - & Abs. & - & Abs. & - & \\
\hline Total coliforms & $\mathrm{MPN} / 100 \mathrm{~mL}$ & 54.6 & 156.6 & 635.2 & 1059.6 & 275.8 & 690.5 & \\
\hline
\end{tabular}

Abs.: absence; L. D.: method limit of detection; MPN: most probable number, L: lower than; G: greater than.

by the increase of $\mathrm{Ca}$ concentration and alkalinity, and increase in the electrical conductivity, hardness, and TDS (Table 5). This is because $\mathrm{Ca}$ is an element that can provide geochemical mobility by leaching in different horizons during the lateritic weathering [52].

Although levels of $\mathrm{Pb}$ in samples extracted during the drilling of WTS monitoring well are below reference values (Table 2) and the average values obtained from samples of other wells, the relation available- $\mathrm{Pb} / \mathrm{Pb}$ in this laterite profile shows that mobility of this element is higher in the area of deposit of the sludge. It seems contradictory that the WTS has immobilized Pb in the soil and the WTS well have been the monitoring well with the highest concentration of this metal in water among the waterbodies investigated. Remember that average concentrations of $\mathrm{Pb}$ are high in all monitoring wells, even in the upstream wells of the WTS disposal area. In this case, the high natural levels of $\mathrm{Pb}$ can be dissociated from human activity. It is known that under certain conditions, $\mathrm{Pb}$ solubility can be increased. Between $\mathrm{pH}$ of 6 and 8 , solubility of $\mathrm{Pb}$ is a complex function of $\mathrm{pH}$ and free $\mathrm{CO}_{2}$ [53]. Under low alkalinity and $\mathrm{pH}$ below 6.5, water may have a significant increase in the solubility of $\mathrm{Pb}$, reaching values as high as several hundred of $\mu \mathrm{g} / \mathrm{L}$ [54]. Therefore, as the wells had these conditions, the explanation for high levels of $\mathrm{Pb}$ can be attributed more to the groundwater characteristics than to the WTS disposal itself. In other words, the WTS is not the source of $\mathrm{Pb}$ to the groundwater but, indirectly, changes in the hydrochemistry, as the increase of $\mathrm{pH}$ and alkalinity, may be increasing chemical activity and allowing the mobilization of $\mathrm{Pb}$, since WTS is the source of bicarbonates and Ca. It is possible that the application of some compounds to correct the soil $\mathrm{pH}$, which is not considered as a pollutant, produces similar effects as the WTS.

\section{Conclusions}

The upper portion from the lateritic profile of the chemical sludge storage area showed positive anomalies of organic matter, cation exchange capacity, potential acidity, 
exchangeable-Ca, exchangeable-Na, available-Mn, available$\mathrm{P}$, and $\mathrm{Mn}$, as well as negative anomalous values of $\mathrm{pH}$ and available- $\mathrm{Pb}$, which are evidences of the noninert character of this material.

Although the investigated groundwater is considered weakly mineralized (trace minerals water), infiltration and percolation of rainwater through the WTS have caused the migration of total dissolved solids to the groundwater, especially in the form of bicarbonates and $\mathrm{Ca}$. It is possible that this effect has mobilized $\mathrm{Pb}$ and had caused an increase in the already high concentrations of this chemical element in the groundwater. However, after ten years of WTS disposal in the gravel pit, the environmental impact on the groundwater can be considered low, because changes in chemical composition of these waters in the Piper diagram were not even noticed.

Thus, the WTS can be considered a noninert residue if disposed in degraded areas located in regions with similar geological and hydrochemical characteristics.

\section{Acknowledgments}

The authors would like to thank Professor Carlos Abs da Cruz Bianchi for helpful discussions and CNPq and CAESB for funding.

\section{References}

[1] F. R. A. Bidone, C. M. B. De Castro, and N. Aboy, "Monitoramento de parâmetros físico/químicos de lodos de ETAS durante a sua desidratação em leitos de secagem com diferentes espessuras de leito drenante," in Anais em $19^{\circ}$ Congresso Brasileiro de Engenharia Sanitária e Ambiental, ABES, Foz do Iguaçu, Brazil, 1997, CD-Rom.

[2] L. Di Bernardo, P. S. Scalize, P. Fragiacomo, J. C. Trofino, and M. A. P. Viudes, "Clarificação da água de lavagem de filtros de sistemas de filtração direta ascendente e desaguamento do lodo por centrifugação," in Anais em $20^{\circ}$ Congresso Brasileiro de Engenharia Sanitária e Ambiental, pp. 1555-1565, ABES, Rio de Janeiro, Brazil, 1999, Cd-Rom (II-084).

[3] M. P. S. Parsekian, Análise e proposta de formas de gerenciamento de estações de tratamento de águas de abastecimento completo em cidades de porte médio do Estado de São Paulo, Dissertação de Mestrado, Escola de Engenharia de São Carlos/USP, São Carlos, Brazil, 1998.

[4] C. V. Andreoli, Resíduos Sólidos do Saneamento: Processamento, Reciclagem e Disposição Final, Projeto PROSAB, RiMa, ABES, Rio de Janeiro, Brazil, 2001.

[5] R. C. A. Moreira, G. R. Boaventura, C. T. C. Nascimento, E. M. Guimarães, and R. P. Oliveira, "Uso do Lodo Químico, Rico em Alumínio, produzido pela Estação de Tratamento de Água Rio Descoberto para a recuperação de uma área degradada," Geochimica Brasiliensis, vol. 21, no. 1, pp. 22-35, 2007.

[6] J. S. Cordeiro, "Importância do tratamento e disposição adequada dos lodos de ETAs," in Noções Gerais de Tratamento de Disposição Final de Lodos de ETA, M. A. P. Reali, Ed., pp. 1-19, ABES/PROSAB, Rio de Janeiro, Brazil, 1999.

[7] L. C. G. T. Machado, M. X. Ponte, L. N. A. Lopes, and J. A. R. Pereira, "Utilização de resíduo de ETA como insumo agrícola," in Anais dos do $23^{\circ}$ Congresso Brasileiro de Engenharia Sanitária e Ambiental, Cuiabá, Brazil, 2005, CD-ROM.
[8] R. M. Barbosa, J. Povinelli, O. Rocha, and E. L. G. Espíndola, "A toxicidade de despejos (lodos) de estações de tratamento de água à Daphnia similis (CLADOCERA, CRUSTACEA)," in Anais do XXVII Congresso Interamericano de Engenharia Sanitária e Ambiental, Porto Alegre, Brazil, 2000.

[9] D. B. George, S. G. Berk, V. D. Adams et al., "Toxicity of alum sludge extracts to a freshwater alga, protozoan, fish, and marine bacterium," Archives of Environmental Contamination and Toxicology, vol. 29, no. 2, pp. 149-158, 1995.

[10] R. B. Sotero-Santos, O. Rocha, and J. Povinelli, "Evaluation of water treatment sludges toxicity using the Daphnia bioassay," Water Research, vol. 39, no. 16, pp. 3909-3917, 2005.

[11] S. Agyin-Birikorang, G. A. O'Connor, L. W. Jacobs, K. C. Makrins, and S. R. Brinton, "Long-term phosphorus immobilization by a drinking water treatment residual," Journal of Environmental Quality, vol. 36, no. 1, pp. 316-323, 2007.

[12] S. Agyin-Birikorang and G. A. O'Connor, "Lability of drinking water treatment residuals (WTR) immobilized phosphorus: aging and $\mathrm{pH}$ effects," Journal of Environmental Quality, vol. 36, no. 4, pp. 1076-1085, 2007.

[13] R. M. Bayley, J. A. Ippolito, M. E. Stromberger, K. A. Barbarick, and M. W. Paschke, "Water treatment residuals and biosolids coapplications affect semiarid rangeland phosphorus cycling," Soil Science Society of America Journal, vol. 72, no. 3, pp. 711719, 2008.

[14] E. A. Dayton and N. T. Basta, "Use of drinking water treatment residuals as a potential best management practice to reduce phosphorus risk index scores," Journal of Environmental Quality, vol. 34, no. 6, pp. 2112-2117, 2005.

[15] J. E. Hyde and T. F. Morris, "Phosphorus availability in soils amended with dewatered water treatment residual and metal concentrations with time in residual," Journal of Environmental Quality, vol. 29, no. 6, pp. 1896-1904, 2000.

[16] A. M. Mahdy, E. A. Elkhatib, and N. O. Fathi, "Drinking water treatment residuals as an amendment to alkaline soils: effects on the growth of corn and phosphorus extractability," International Journal of Environmental Science and Technology, vol. 4, no. 4, pp. 489-496, 2007.

[17] O. O. Oladesi, G. A. O'Connor, J. B. Sartain, and V. D. Nair, "Controlled application rate of water treatment residual for agronomic and environmental benefits," Journal of Environmental Quality, vol. 36, no. 6, pp. 1715-1724, 2007.

[18] E. Lenzi, E. M. Nogami, D. Galli, and M. M. Morales, "Estudo do lodo da ETA de Maringá (PR) e seu possível destino," in Anais do dos $22^{\circ}$ Congresso Brasileiro de Engenharia Sanitária e Ambiental, Joinville, Brazil, 2005, CD-ROM.

[19] A. A. Moreira, J. A. Silva, A. C. S. Cardim, J. L. Argolo, A. Schiavetti, and E. S. Martins, "Análise do material em suspensão da represa do Descoberto/DF e sua reutilização em áreas degradadas," in Resumo Expandido, IX Congresso Brasileiro de Geoquímica, pp. 76-78, 2003.

[20] A. B. D. Barbosa, "A experiência da CAESB em recuperação de água de lavagem de filtros e desidratação de lodo de ETA," in Anais em do $19^{\circ}$ Congresso Brasileiro de Engenharia Sanitária e Ambiental, ABES, Foz do Iguaçu, Brazil, 1997, CD-Rom.

[21] Sebrae, A Questão Ambiental no Distrito Federal, Edição SEBRAE/DF, Brasília, Brazil, 2004.

[22] M. M. Barroso and J. S. Cordeiro, "Metais e sólidos: aspectos legais dos resíduos de estação de tratamento de água," in Anais do $21^{\circ}$ Congresso Brasileiro de Engenharia Sanitária e Ambiental, João Pessoa, Brazil, 2001, CD-ROM. 
[23] M. D. S. Pereira and B. F. Dos Reis, "Determinação espectrofotométrica de alumínio em concentrados salinos utilizados em hemodiálise empregando pré-concentração em fluxo," Química Nova, vol. 25, no. 6, pp. 931-934, 2002.

[24] E. Merian and T. W. C. Clarkson, Metals and Their Compounds in the Environment: Occurrence, Analysis and Biological Relevance, VCH, Weinheim, Germany, 2nd edition, 1991.

[25] C. L. Echart and S. Cavalli-Molina, "Fitotoxicidade do alumínio: efeitos, mecanismo de tolerância e seu controle genético," Ciência Rural, vol. 31, no. 3, pp. 531-541, 2001.

[26] L. Di Bernardo, A. Di Bernardo, and P. L. Centurione Filho, Ensaios de Tratabilidade de Água e dos Resíduos Gerados em Estações de Tratamento de Água, RiMa Editora, São Carlos, Brazil, 1st edition, 2002.

[27] A. B. D. Barbosa, M. A. Morato, M. N. Borges et al., "Plano de monitoramento da estação de tratamento rio Descoberto," Relatório Interno, CAESB, Brasília, Brazil, 2003.

[28] J. E. G. Campos and F. H. Freitas-Silva, "Geologia," in Olhares Sobre o Lago Paranoá, F. O. Fonseca, Ed., Secretaria do Meio Ambiente e Recursos Hídricos, Brasília, Brazil, 2001.

[29] F. H. Freitas-Silva and J. E. G. Campos, "Geologia do parque nacional de Brasília-DF," Boletim de Geociências do CentroOeste, vol. 18, no. 1-2, pp. 32-43, 1995.

[30] J. E. G. Campos and F. H. Freitas Silva, Inventário Hidrogeológico e dos Recursos Hídricos Superficiais do Distrito Federal, vol. 4 of Relatório Técnico Hidrogeologia do Distrito Federal, IEMA/UnB, Brasília, Brazil, 1998.

[31] R. C. A. Moreira, E. M. Guimarães, G. R. Boaventura, A. M. Momesso, and G. L. De Lima, "Estudo geoquímico da disposição de lodo de ETA em área degradada," Química Nova, vol. 32, no. 8, pp. 2085-2093, 2009.

[32] APHA-AWWA-WPCF, Standard Methods for Examination of Water and Wastewater, APHA-AWWA-WPCF, Washington, DC, USA, 20th edition, 1998.

[33] W. M. Telford, L. P. Geldart, R. E. Sheriff, and D. A. Keys, Applied Geophysics, Cambridge University Press, Cambridge, UK, 1985.

[34] C. W. Fetter, Applied Hydrogeology, Macmillan College Publishing Company, New York, NY, USA, 3rd edition, 1994.

[35] O. Koefoed, Resistivity Sounding Measurements, Elsevier, Amsterdam, The Netherlands, 1979.

[36] R. Van Nostrand and K. L. Cook, Interpretation of Resistivity Data; Geological Survey, Professional Paper 499, United States Geological Survey, Washington, DC, USA, 1966.

[37] Embrapa, Manual de Métodos de Análise de Solo, Ministério da Agricultura e do Abastecimento, Rio de Janeiro, Brazil, 2nd edition, 1997.

[38] G. R. Boaventura, "Performance do Espectrômetro de Emissão com Plasma (ICP), spectroflame FVM03, para determinação de 20 elementos químicos nas amostras de referência geoquímica DNC-1, W-2, UNB-B1 e UNB-G2," in Proceedings of the III Congresso Brasileiro de Geoquimica, vol. 2, pp. 423426, São Paulo, Brazil, 1991.

[39] G. M. Rohde, Geoquímica Ambiental e Estudos de Impacto, Editora Signus, São Paulo, Brazil, 2nd edition, 2004.

[40] S. A. Mingoti, Análise de Dados Através de Métodos de Estatística Multivariada-Uma Abordagem Aplicada, Editora UFMG, Belo Horizonte, Brazil, 1st edition, 2007.

[41] U. Förstner, "Contaminated sediments," in Lecture Notes in Earth Sciences, S. Bhattacharji, G. M. Fridman, H. J. Neugebauer et al., Eds., vol. 21, pp. 1-157, Springer, Berlin, Germany, 1989.
[42] Gradient, SOUNDER: Program for Interactive Multi-Layer Resistivity Modeling, Gradient Geology and Geophysics, Missoula, Mont, USA, 1991.

[43] M. H. Loke, RES2DINV 3.2 for WINDOWS; Rapid 2D Resistivity \& IP Inversion Using the Least-Squares Method, Geoelectrical Imaging 2D \& 3D, 1997.

[44] Associação Brasileira de Normas Técnicas (ABNT), Resíduos Sólidos-Classificação, vol. 2 of NBR 10004, ABNT, Rio de Janeiro, Brazil, 2004.

[45] W. Schellmann, "On the geochemistry of laterites," Chemie der Erde, vol. 45, pp. 39-52, 1980.

[46] M. L. Costa, "Introdução ao intemperismo laterítico e à laterização," in Prospeç̧ão Geoquímica-Depósitos Minerais Metálicos, Não-Metálicos, Óleo e Gás, O. A. B. Licht, C. S. B. Mello, and C. R. Silva, Eds., p. 788, Sociedade Brasileira de Geoquímica / CPRM, Rio de Janeiro, Brazil, 2007.

[47] L. R. G. Guilherme, J. J. Marques, M. A. P. Pierangeli, D. Q. Zuliane, M. L. Campos, and G. Marchi, "Elementos-traço em solos e sistemas aquáticos," Tópicos em Ciência do Solo, vol. 4, pp. 345-390, 2005.

[48] M. A. Cambri, Tese de Doutorado em Agronomia, Escola Superior de Agricultura Luiz de Queiroz, Universidade de São Paulo, Piracicaba, Brazil, 2004.

[49] L. L. Leite, C. R. Martin, and M. Haridasan, Anais do Simpósio Nacional sobre Recuperação de Áreas Degradadas, Curitiba, Brazil, 1992.

[50] R. M. M. Santos, M. M. Souza, R. C. A. Moreira, K. Hatting, and P. Q. Araújo, "Monitoramento como instrumento de gestão de águas subterrâneas no Distrito Federal," in Resumos do XI Congresso Brasileiro de Geoquímica, Atibaia, Brazil, 2007.

[51] G. R. Boaventura and A. L. S. Freitas, "Inorganic parameters as water quality indicators in acidic groundwater in a tropical region-Brasilia-DF (Brazil)," Water, Air, and Soil Pollution, vol. 171, no. 1-4, pp. 135-151, 2006.

[52] R. R. Anand and M. Paine, "Regolith geology of the Yilgarn Craton, Western Australia: implications for exploration," Australian Journal of Earth Sciences, vol. 49, no. 1, pp. 3-162, 2002.

[53] Canadá, Guidelines for Canadian Drinking Water Quality, Federal Provincial Advisory Committee on Environmental and Occupational Health and Welfare, Ottawa, Canada, 1993.

[54] R. Pitt, S. Clark, and K. Parmer, Potential Groundwater Contamination from Intentional and Nonintentional Stormwater Infiltration, Diane Publishing, 1994. 

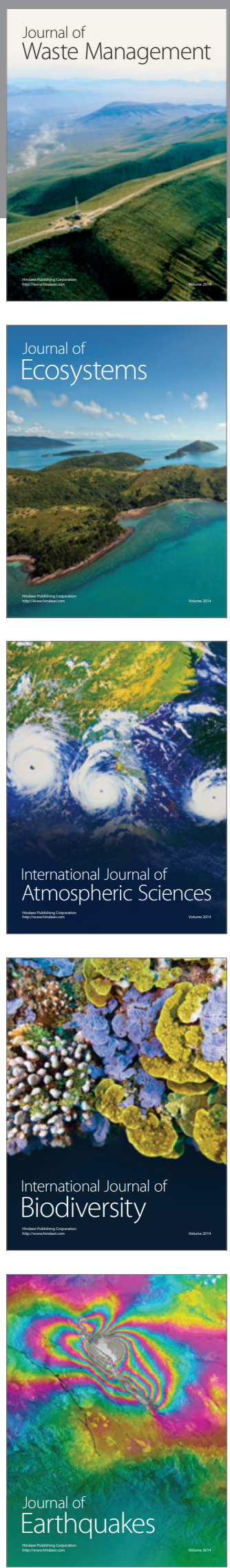
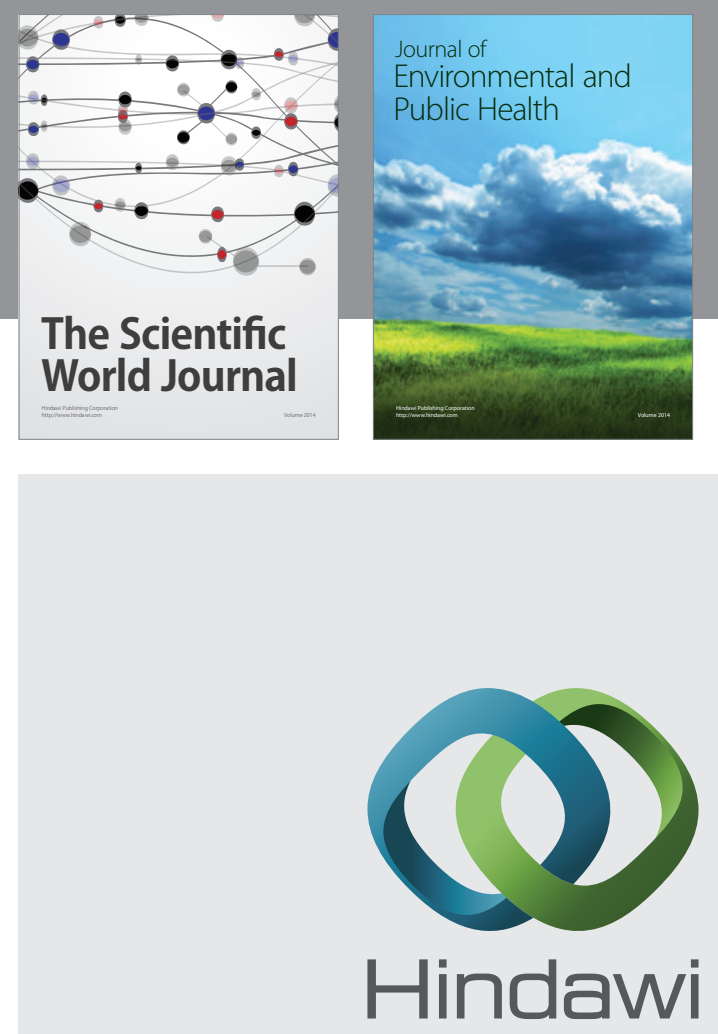

Submit your manuscripts at

http://www.hindawi.com
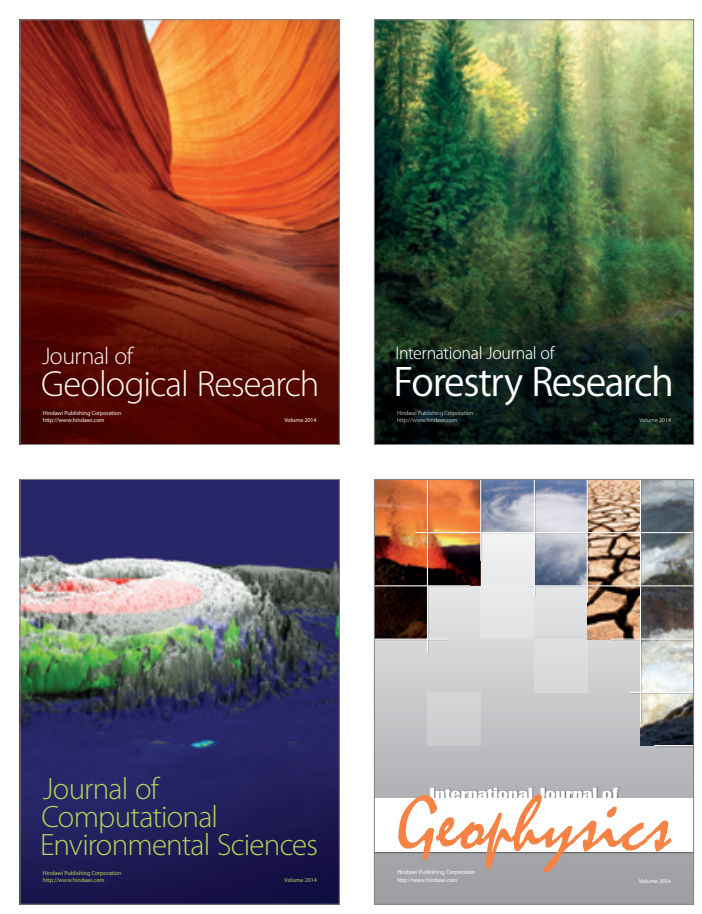
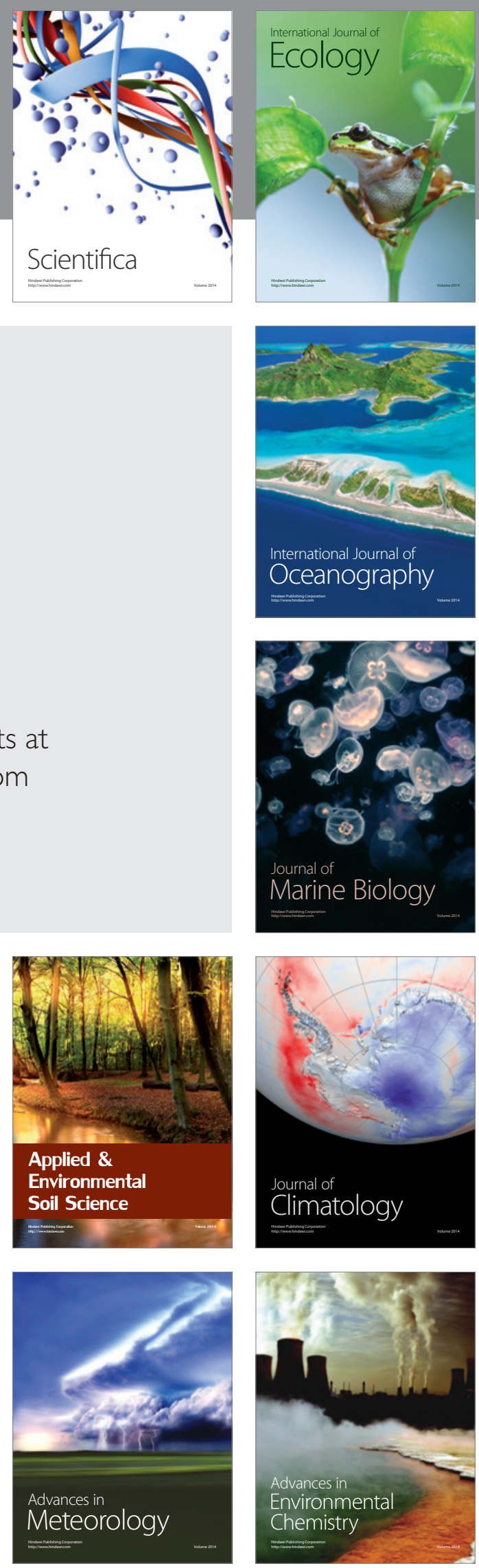